Review Article

\title{
The History of Methicillin-Resistant Staphylococcus aureus in Brazil
}

\author{
Mariana Moreira Andrade, ${ }^{1,2}$ Wilson Barros Luiz, ${ }^{2}$ Rayane da Silva Oliveira Souza, \\ and Jaime Henrique Amorim $\mathbb{D i D}^{1,2}$ \\ ${ }^{1}$ Laboratório de Agentes Infecciosos e Vetores, Centro Das Ciências Biológicas e da Saúde, \\ Universidade Federal Do Oeste da Bahia, Barreiras, Bahia, Brazil \\ ${ }^{2}$ Programa de Pós-graduação em Biologia e Biotecnologia de Microrganismos, Universidade Estadual de Santa Cruz, \\ Ilhéus, Bahia, Brazil \\ Correspondence should be addressed to Jaime Henrique Amorim; jaime.amorim@ufob.edu.br
}

Received 9 March 2020; Revised 21 July 2020; Accepted 24 September 2020; Published 7 October 2020

Academic Editor: Peter J. Weina

Copyright (c) 2020 Mariana Moreira Andrade et al. This is an open access article distributed under the Creative Commons Attribution License, which permits unrestricted use, distribution, and reproduction in any medium, provided the original work is properly cited.

\begin{abstract}
Since the emergence of MRSA in the 1960s, a gradual increase in infections by resistant bacteria has been observed. Clinical manifestations may vary from brand to critical condition due to host risk factors, as well as pathogen virulence and resistance. The high adaptability and pathogenic profile of MRSA clones contributed to its spread in hospital and community settings. In Brazil, the first MRSA isolates were reported in the late 1980s, and since then different genetic profiles, such as the Brazilian epidemic clone (BEC) and other clones considered a pandemic, became endemic in the Brazilian population. Additionally, Brazil's MRSA clones were shown to be able to transfer genes involved in multidrug resistance and enhanced pathogenic properties. These events contributed to the rise of highly resistant and pathogenic MRSA. In this review, we present the main events which compose the history of MRSA in Brazil, including numbers and locations of isolation, as well as types of staphylococcal cassette chromosome mec (SCCmec) found in the Brazilian territory.
\end{abstract}

\section{Introduction}

Outbreaks of nosocomial and community-associated infections with methicillin-resistant Staphylococcus aureus (MRSA) have been reported as highly relevant worldwide. Attention to such pathogenic bacteria increased progressively since the first reports of resistance to antimicrobial agents. Penicillin was the first antibiotic to be introduced in clinical practice, in 1940. Shortly after, the selection of $\beta$-lactamase-producing bacteria marked the beginning of the first wave of antibiotic resistance in Staphylococcus aureus (S. aureus), which continues today [1].

The rapid spread of penicillin resistance briefly came to a halt after the introduction of the second-generation, semisynthetic methicillin in the 1960s. However, MRSA soon emerged in England, and only in 1981, this mechanism of resistance was unraveled: these strains harbored mutant penicillin-binding proteins, designated PBP-2a, which showed a reduced affinity for methicillin. PBP-2a is encoded by $m e c A$, a gene located in the S. aureus chromosome [2]. Thereafter, new cases of hospital-acquired infections were reported in other countries such as Australia and the United States $[3,4]$. Due to the use of new antibiotics, a slight decrease in MRSA prevalence was noticed. However, because of selective pressure, strains of $S$. aureus began to display a multidrug resistance profile. Cases of MRSA resistant to both $\beta$-lactams and gentamicin began to be reported in health units at the end of the 1970s [5-7]. In the 1980s, reports of outbreaks and infections caused by MRSA increased gradually.

The genetic profile of MRSA began to be clarified only after 1999, when the gene coding a mutated form of the PBP of the N315 resistant clone isolated in Japan, in 1982, was discovered [8]. In 2001, it was reported that such a sequence 
was inserted into a mobile cassette within the chromosomal DNA, called staphylococcal cassette chromosome mec (SCCmec). Thereafter, the first three isolates of SCCmeccontaining $S$. aureus were used to designate the first three types of cassettes, in order of isolation [9]. To date, fourteen types of SCCmec were described in S. aureus $[10,11]$. They were identified according to different combinations of components of their sequences, including the mec complex, the cassette chromosome recombinase (ccr) complex, and J regions $[10,12]$.

Brazil is the largest country in Latin America and the $5^{\text {th }}$ largest country in the world. Reviewing the history of MRSA in Brazil will help to better understand the spread of this important pathogen in Latin America, as well as in the new world. In Brazil, there are some epidemiological surveillance systems of resistant bacteria which do not work at a national level $[13,14]$. However, in 2018, a program named PAN-BR (National Action Plan for the Prevention and Control of Antimicrobial Resistance in Brazil) was developed [15]. Although it is not specific for the control and monitoring of MRSA, it was designed based on objectives pre-established by organizations, such as the World Health Organization, and aims to apply strategies for the prevention, control, and monitoring of infections caused by antimicrobial-resistant pathogens, including MRSA. One of the strategic objectives of PAN-BR is "to strengthen knowledge and the scientific basis through surveillance and research" [15]. Therefore, the data provided in this review will contribute to the performance and development of this program, as well as other strategic action plans suggested by the Agência Nacional de Vigilância Sanitária (ANVISA) for the prevention and control of resistance in the country [16].

In this review, we present the history of MRSA in Brazil. Numbers and locations of isolation, as well as types of SCCmec found in the Brazilian territory, are discussed in sections by decade, since the 1980s. As inclusion criteria, all published studies reporting the isolation of MRSA from human samples in Brazil were used in this review. In addition, the prevalence of MRSA by region, as well as the frequency types of SCCmec, is shown. Text sections are concentrated on a critical review of the main events which compose the history of MRSA in Brazil. The articles were searched in MEDLINE/PubMed and SciELO databases by using the keywords "MRSA Brazil." We found 597 articles, and after applying exclusion and inclusion criteria, 199 articles were selected.

1.1. The 1980s. The first cases of MRSA in Brazil were reported in 1987 in Rio de Janeiro, and although they were not published, these events were mentioned by Ramos et al. in 1999 [17]. Such publication was the only one to report MRSA in the 1980s in Brazil, as shown in Figure 1. The incidence of MRSA was reported to be approximately $8 \%$. Variances in the occurrence of MRSA isolates were reported in the following two years: with a decrease of $7.2 \%$ in 1988 and the following increase to 33\% in 1989 [17]. From 1987 to 1994, Tresoldi and colleagues reported that 257 of 421 S. aureus isolates were MRSA. However, although S. aureus

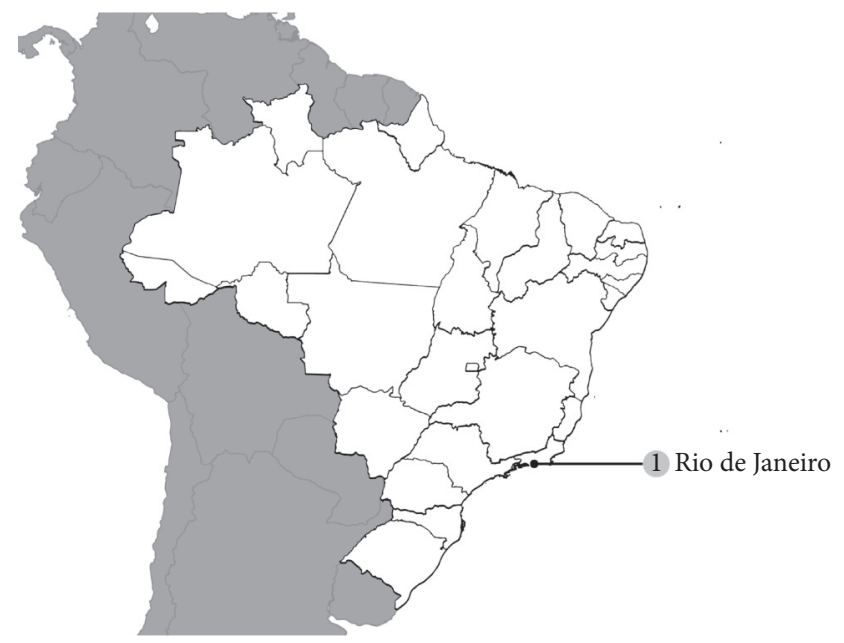

FIgURE 1: Map with georeference of MRSA reports showing the number of publications by isolation location during the 1980 s.

is to be isolated with the highest frequency (20.9\%), MRSA isolates in this study were reported only in the 1990s by Tresoldi and colleagues [18].

After the global spread of MRSA, new antimicrobial agents, such as Synercid, daptomycin, linezolid, and tigecycline, were introduced during the treatment of infections caused by methicillin-resistant bacteria, which may have contributed to broadening mechanisms of multidrug resistance [19-23]. In a study published in 1989, which involved 106 strains of $S$. aureus from 21 countries, including Brazil, $90 \%$ of the samples were shown to be multiresistant to antimicrobial agents. Relevantly, the Brazilian strains showed resistance to fourteen antibiotics in this same study [24].

1.2. The 1990s. The first three waves of resistance of S. aureus of antimicrobial drugs were characterized based on its spread specifically in health care environments. The first wave was characterized by the emergence of strains capable of producing penicillinase, which inactivates penicillin. The emergence of MRSA strains marked the second wave. The disappearance of the archaic clone and the raise of new clones marked the third resistance wave [25]. The fourth wave has been marked by the introduction of communityacquired MRSA (CA-MRSA). However, the hospital clones were still prevalent in Brazil in the 1990s [26]. Compared to the 1980s, the number of occurrences of MRSA increased gradually in different health care facilities in Brazil $[17,27-30]$. The spread of MRSA continued to be reported in different hospitals in São Paulo [31, 32]. Restriction fragment length polymorphisms (RFLP) showed the spread of MRSA clones, which indicated that microbial transfer was occurring possibly due to an interhospital connection involving patients and health workers [31,32]. Furthermore, 91 MRSA isolates were found as microbiota composing of hospital food handlers in Teresina [33]. Such results indicated that transmission by physical contact was a determining factor of the occurrence for nosocomial outbreaks caused by both susceptible and resistant $S$. aureus [34, 35]. 
The theory of interhospital connection was reinforced when the same clone of MRSA was isolated from different locations at the same hospital in Joao Pessoa, in 1992 [36] and thereafter was found in the Campinas University Hospital, in two different studies $[18,37]$. Such a clone was shown to be the same one found by Sader et al. in São Paulo, in 1993 and 1994 [31, 32]. The spread of MRSA was also shown to happen in an intrahospital way, as reported by a study carried out in Rio de Janeiro, in which propagation of a single virulent multidrug-resistant clone within the same hospital caused a relevant number of deaths [38].

A study carried out in five Brazilian cities showed in a systematic way that the interhospital communication was not restricted to nearby areas due to the spreading of bacteria with the same genetic pattern to different regions of the country [39]. Such a genetic pattern was identified by pulsed-field gel electrophoresis (PFGE) of chromosomal DNA. The epidemic MRSA was named as Brazilian epidemic clone (BEC) and became one of the five most-discussed MRSA clones around the world [28, 39]. Epidemiological studies aiming to investigate the spread of BEC were carried out in the 1990s in both Brazil and other countries, such as Portugal, Argentina, Chile, and Italy [28, 40-42]. MRSA strains containing both the polymorphic form type XI of the mec gene and type $\mathrm{B}$ of the Tn554 gene were classified as the A genetic pattern of BEC (BEC A). Although this pattern has been identified more frequently, some studies have isolated MRSA that differed minimally from BEC A. Such variants, including $\mathrm{BEC} \mathrm{A}$, were grouped as the Brazilian epidemic clonal complex (BECC) [30,43].

After such reports, BEC was massively searched in several hospitals of Brazil evidencing its wide geographical distribution and predominance $[42,44]$. The study by Oliveira et al. showed that from 83 MRSA isolated in 14 states in Brazil, $78.3 \%$ contained the mecA gene with polymorphism XI and Tn554 type B (BEC A). Moreover, isolates were shown to be multiresistant to drugs. These results clearly showed the spread of the BEC and its variants in Brazil $[45,46]$.

Genetic patterns of BECC isolates were shown to be diverse regarding their antimicrobial resistance and pathogenicity such as to be capable of forming biofilm and adhere and invade airway epithelial cells [30, 47]. The multiresistance is another common feature among BECC isolates. They carry structures such as plasmids and transposons that are responsible for resistance to other drugs within the cassette. In addition to methicillin, strains may be resistant to clindamycin, erythromycin, cephalothin, gentamicin, ciprofloxacin, sulfamethoxazole-trimethoprim, and chloramphenicol [39]. These strains have also shown high-level resistance to mupirocin. It is due to the insertion of the PMG1 plasmid, which carries a novel ileS gene that encodes a novel isoleucyl-tRNA synthetase, homolog to antibiotic target [48-50]. Such multiresistance presented by MRSA and the high frequency of nosocomial infections are associated with risk factors such as insertion of classic pathogens into host microbiota, prolonged hospitalization, and misuse of antibiotics [51-53]. This ability to adapt is probably related to genetic diversity into the BECC reported in different published studies $[54,55]$. These reports indicated a relevant genetic diversity into the BECC at the ending of the 1990s.

Therefore, other clones or subclones were reported in Brazilian hospitals. The first report of non-BEC MRSA, which presented different genetic patterns from that characterized by BEC, such as mecA type III and Tn544 type B polymorphism, was carried out in 1996 [56]. Although there were reports of diversity in genetic profiles, the BEC A was still prevalent among the isolates, as occurred in Teresina, Rio de Janeiro, Uberlandia, and Belem [30, 49, 57, 58]. However, the type of SCCmec was not yet known. In the 2000s, it was reported that the BEC clone carries the SCCmec type III. Such a cassette type was thus shown to be the most frequent in Brazil in the 1990s [55, 59]. The number of MRSA isolation reports published in the 1990s is shown in Figure 2.

1.3. The 2000s. In the 2000s, MRSA remained a concern in Brazil, with new records in the prevalence of resistant bacteria, with an increase in the number of cases of infections [60]. Figure 3 shows the number of reports by location published in this decade. Strains of the BECC continued to be predominant in Brazilian hospitals until a certain moment $[29,61-66]$. However, over the decade, other international (non-BEC) clones were imported and started to be reported in different regions of Brazil [67, 68]. Such international clones carried other types of cassettes and were named according to the location they were isolated for the first time [69]. Some of these clones, although considered pandemic, were reported less frequently in Brazil, such as the Iberian clone (SCCmec type I); the Hungarian clone (SCCmec type III); Cordobes/Chilean clone (SCCmec type I); an MRSA clone carrying SCCmec type V [69-71]. However, other clones considered to be of great relevance in a global context were reported in a larger frequency. One of these clones was the New York/Japan clone, which is also classified as HA-MRSA (hospital-acquired MRSA) but carrying SCCmec type II. Such a clone was initially isolated in a lower frequency with regard to the BEC. Nevertheless, it was gradually spread in the hospital environment $[47,65,71-73]$. Its fixation in Brazilian hospitals was a milestone in history because, in addition to its spread, the New York/Japan clone presented resistance to $\beta$-lactam antibiotics, ciprofloxacin, erythromycin, and clindamycin, hindering the treatment of patients [74].

The pediatric clone, which is of great world relevance, had also an important role in the history of MRSA in Brazil. It carries the SCCmec type IV, which is commonly present in strains of CA-MRSA. However, although not classified as HA-MRSA, it was reported in a relevant number of nosocomial infections. Its profile of resistance diverges from most of HA-MRSA, presenting a susceptibility to a wide range of antimicrobial agents, except $\beta$-lactams. Although nonmultidrug resistant, the pediatric clone began to exhibit important virulence factors. Isolates obtained in different cities showed the capacity of forming biofilm and of producing enterotoxins. Such virulence factors increase the 


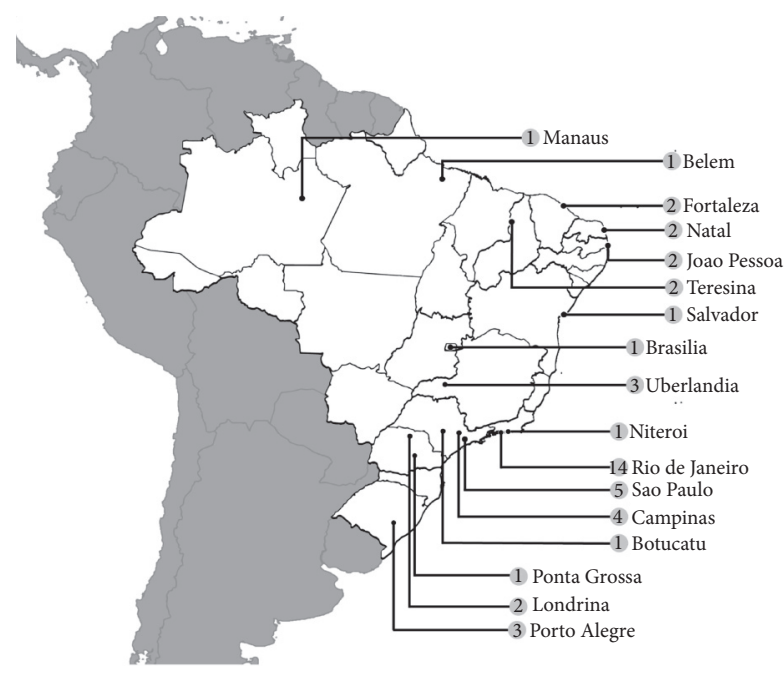

Figure 2: Map with georeference of MRSA reports showing the number of publications by isolation location during the 1990s.

bacterial pathogenicity, exacerbating infections mainly in immunocompromised, children, and elderly $[47,72,75,76]$.

The pediatric clone has similarities and divergences with another clone that also gained prominence: the Oceania Southwest Pacific (OSP) clone. In common, both carry SCCmec type IV and are typically non-multiresistant. However, different from the pediatric clone, the OSP clone was shown to cause infections in the community [77]. Community MRSA strains were first reported in western Australia in the early 1990s [78]. Such strains were initially devoid of Panton-Valentine leucocidin (PVL), but subsequent cases of community MRSA were now recorded as PVL positive [79]. Such a clone was first described in Brazil as CA-MRSA before being isolated from patients with skin and soft tissue infections which were not exposed to classical risk factors for nosocomial infection [80]. Several infections caused by CA-MRSA ranging from mild [81-85] to severe [86-88] were reported in Brazil in the 2000s. Although the properties of CA-MRSA appear to make it less aggressive than hospital clones, the OSP clone presents virulence factors involved in the high pathogenicity, such as the PVL, which kills immune cells and induces tissue necrosis $[82,83,86,87,89,90]$. Although originally found in MRSA SCCmec type IV, PVL has also been reported in strains with other types of cassettes mostly present in HA-MRSA strains, such as BEC, due to a horizontal transfer of genes $[29,63,91$, and 92]. Such horizontal transference indicates contact between CA and HA-MRSA. Thus, CA-MRSA was identified in health units, and HA-MRSA clones were identified in the community [74, 93, and 94]. As a result, in addition to the presence of PVL in clones that at the time were considered unusual carriers, the ability to form biofilms was spread among the various types of MRSA $[92,95]$. In addition to the spread of virulence factors, genes of resistance to antimicrobial drugs were transferred to non-multiresistant clones, which resulted in strains with a profile of pathogenicity and resistance [75, 89, and 96].

The spread of different clones was observed in the mid2000s in Brazil [92, 97]. Different clones of MRSA carrying
SCCmec type IV, including CA-MRSA, were detected in 19 of 20 MRSA isolated from patients with nosocomial infections in a hospital of Rio de Janeiro. In Porto Alegre, moreover to the isolation of the OSP clone, the pediatric clone was shown to be circulating [71, 96, 98, and 99]. In São Paulo, a profile similar to CA-MRSA was identified as the cause of $95 \%$ of bloodstream infections. Such reports indicated the adaptive capacity of CA-MRSA to the hospital environment [75].

An important study was published in 2012 describing samples collected in the south, southeast, and northeast of the country and revealed the most frequent cassettes circulating in Brazil. The cassettes were identified based on the detection of clonal complexes (CC) and the most common were shown to be SCCmec types II, III, and IV $[47,64,65,72,100$, and 101]. These cassettes were reported gradually during the decade of 2000, showing that there was an evolution, adaptation, and propagation of different clones of MRSA in Brazil.

1.4. The 2010s. In the 2010s, MRSA remained being increasingly reported in Brazil, as shown in Figure 4. The most common clones in the hospital environment continued to be those carrying the SCCmec types II, III, and IV $[14,65,73,102,103]$. However, SCCmec type II, in contrast to the last decade, was reported as one of the most prevalent clone [103-109]. Relevantly, the New York/Japan clone, which carries SCCmec type II, was shown to become resistant to daptomycin, tigecycline, and vancomycin $[67,110]$. In addition, such a clone was shown to become capable of producing $\alpha$-hemolysin and PVL and forming a biofilm $[14,104,105]$. Thus, multiresistance and virulence remained evolutionary events among MRSA clones. As a further example of adaptation and evolution, in 2011, a CAMRSA strain was shown to have acquired the vanA gene, which confers resistance to vancomycin. This was the first CA-MRSA reported being resistant to this antimicrobial agent [111].

Clones carrying the SCCmec type IV continued to be the main producers of PVL and biofilms $[112,113]$. These virulence factors were involved in infections reported in both hospital and community environments due to a horizontal transfer of genes among CA-MRSA and HA-MRSA strains. In addition to the New York/Japan clone, the production of biofilms and PVL began to be seen in more unusual and less frequent clones, such as those carrying SCCmec types V and I [114, 115]. These types of cassettes, as well as the SCCmec type VI, UK/EMRSA-3, Hungarian, and Iberian clones, were identified in the history of MRSA in Brazil at a low frequency [104, 116-119].

The last relevant chapter of the history of MRSA in Brazil also involves SCCmec V. An unusual genetic profile called clonal complex 398 (CC398) began to be reported. Such variants may carry either type IV or type $\mathrm{V}$ cassettes. This complex is directly associated with livestock and thus called LA-MRSA (livestock-associated methicillin-resistant Staphylococcus aureus). This type of MRSA emerged the first time from animal infection samples, in 1972 [120], but was 


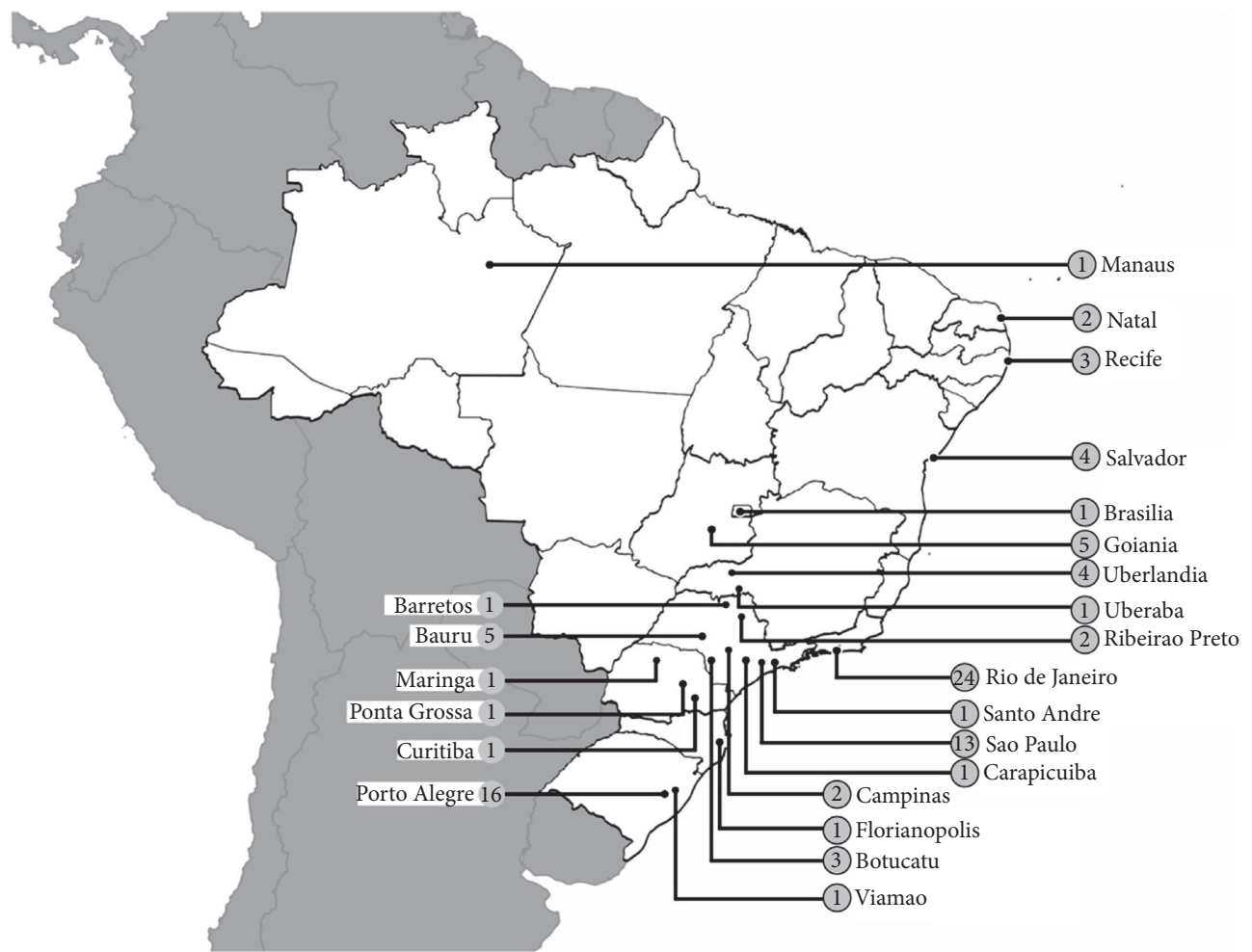

FIGURE 3: Map with georeference of MRSA reports showing the number of publications by isolation location during the 2000 s.

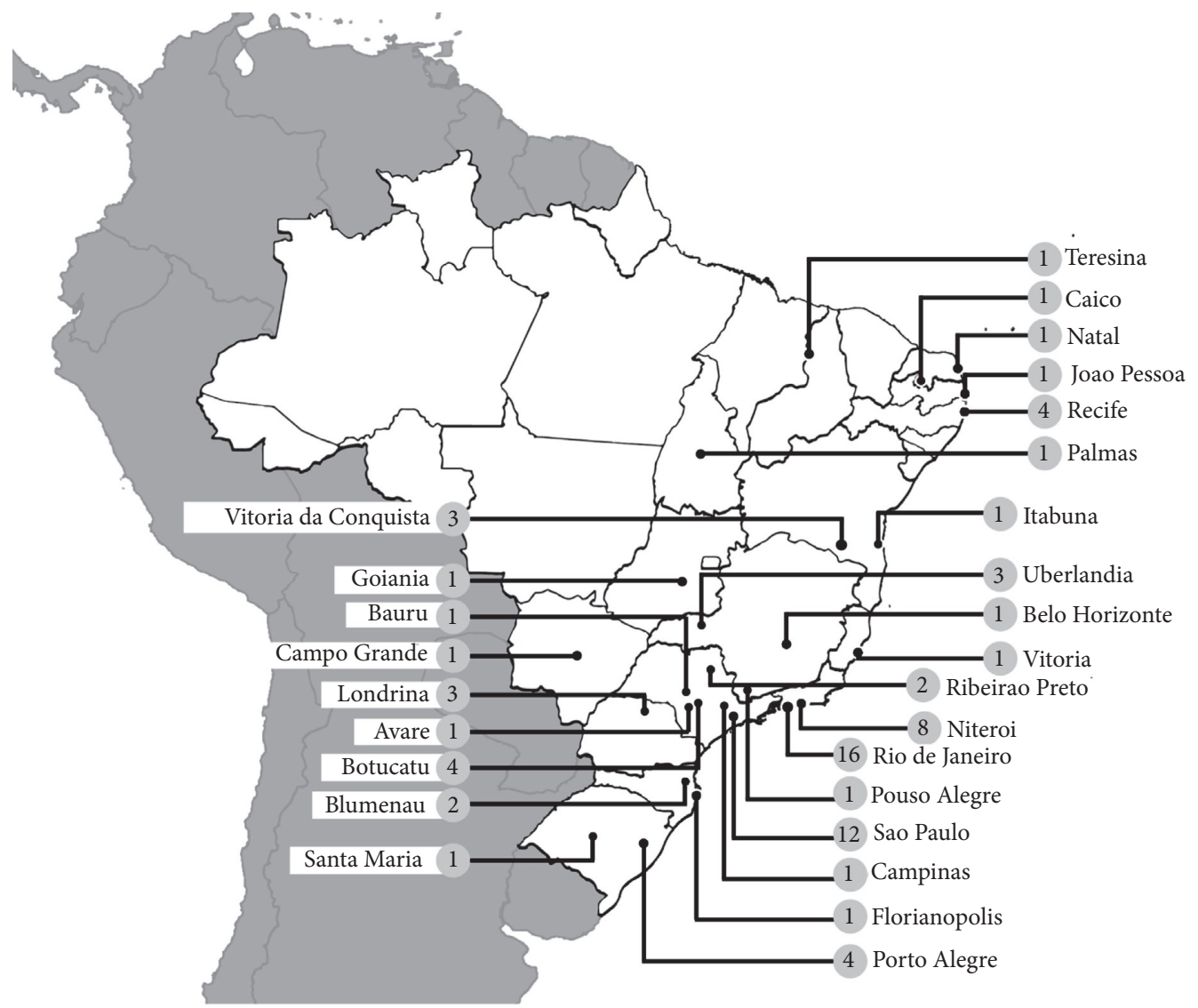

FIGURE 4: Map with georeference of MRSA reports showing the number of publications by isolation location during the 2010s. 


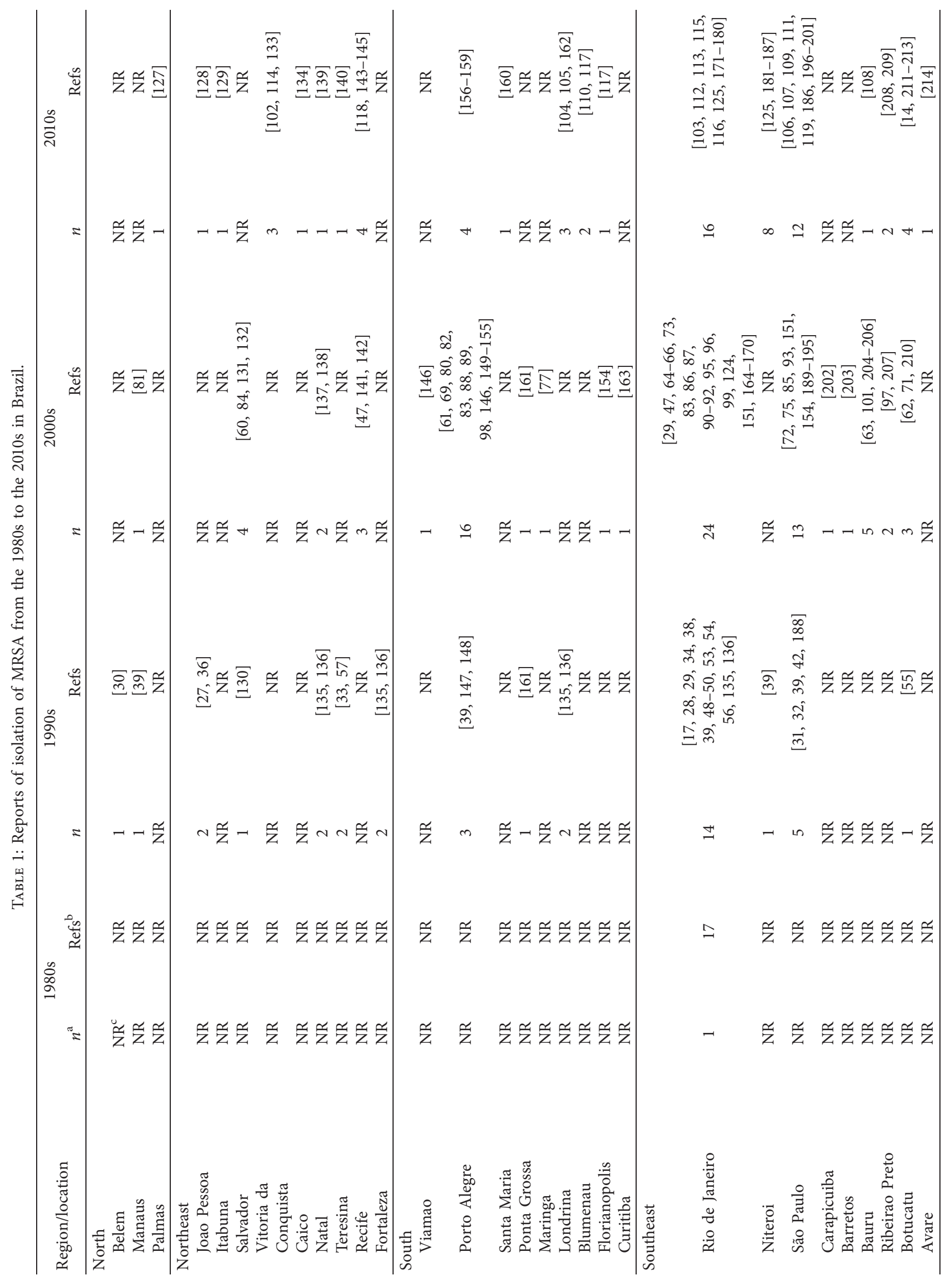




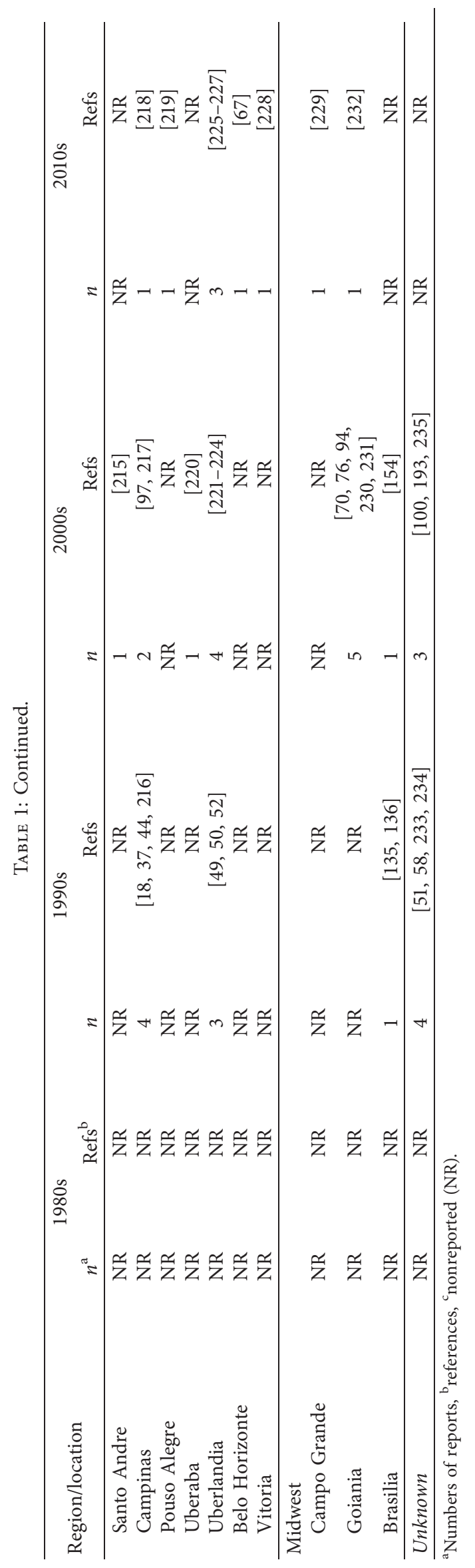




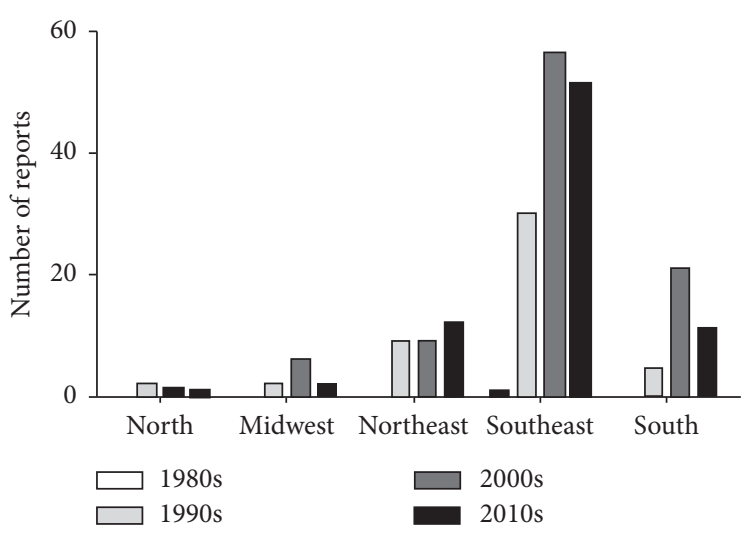

(a)

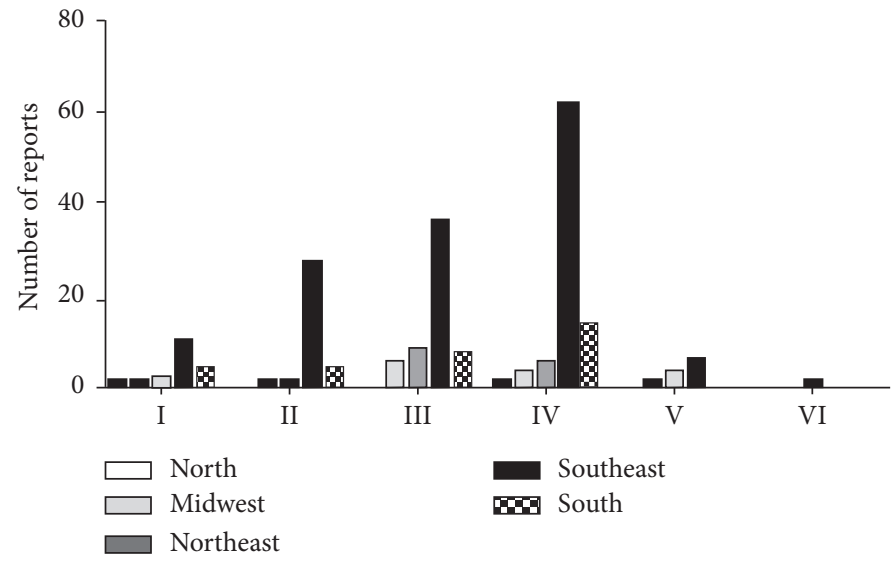

(b)

FIgURE 5: MRSA isolates and the types of SCCmec reported in Brazil. (a) Numbers of MRSA isolations per decade in the five regions of Brazil. (b) Numbers of types of SCCmec reported in the five regions of Brazil until 2019. The graphics program used to create the figure was GraphPad Prism.

subsequently isolated from humans, especially those who had direct access to animals [121-123]. In 2010, it was first isolated in Brazil from a patient with cystic fibrosis who had contact with animals from the farm [124]. Later, between 2011 and 2016, six clones of the same complex were isolated from children in Rio de Janeiro [125]. However, such isolates were not classified as LA-MRSA because the children did not present the typical risk factors for the acquisition of this lineage, which includes the previous contact with animals. These results showed that clones of this lineage are not restricted to animals and have adapted to a new kind of host.

1.5. Clinical and Epidemiological Relevance. The 199 documented articles reflect the high and gradual incidence of pandemic clones disseminated in Brazil and the increase in the proportion of infections that result in different clinical manifestations. Although it is currently part of the PAN-BR, no survey has yet been made of the MRSA rates recorded since its emergence in Brazil until today [15]. However, Brazil is part of an antimicrobial surveillance organization that acts at a global level, called SENTRY, which recorded that $38.7 \%$ of MRSA out of 17474 samples of S. aureus collected over the 20-year interval were from Latin America, including Brazilian sampling [126].

A quantitative survey of reports of MRSA infections specifically in Brazil collaborates to point out how emergency it is to apply the objectives of national epidemiological inspection and control programs [15]. Such a survey based on the regions of Brazil evidences which areas are most affected and which increase the country's epidemiological rates. Table 1 shows all the cities in Brazil and its respective references that were reported through publications that involved isolating MRSA from human samples. It is evident that the spread of clones and the consequences they bring to patients were gradually increased over the years and that all regions of the country have already been notified, with the southeast region being the most affected in all decades, followed by the south and northeast (Figure 5(a)). The high number of MRSA notifications in these regions was probably due to the fact that they are the most populated in Brazil, while the centralwest and north regions have lower demographic density [236]. In all regions, SCCmec type IV is the most prevalent, followed by III, II, and I, demonstrating that the clones that typically circulate in the community are the most prevalent in the country, followed by hospital clones (Figure 5(b)). Such data show how these virulent, highly adaptable, and multidrug-resistant clones pose risks to the population and show that such a survey contributes to the development of prevention and control assistance plans recently adopted in the country.

1.6. Final Considerations. Considering case reports and field research included in this review, it is clear that MRSA is now present in the five regions of Brazil. It is also clear that Brazil has a large genetic diversity of MRSA, including multidrugresistant and high virulent strains. Such diversity may increase if new SCCmec and variants are imported. In addition, it is important to note that the data indicated in this review are relevant but still limited concerning the subcontinental size of Brazil. Limitations may include an insufficient number of studies due to low government investment in research, lack of access to health services for the vulnerable population, and application of empirical antibiotic therapy ignoring established protocols, which undoubtedly results in underreporting of a relevant number of cases. This review reinforces problems related to the ability of bacteria to become resistant to antibiotics and their potential for spread, usually occurring in epidemic waves initiated by one or a few successful clones. Moreover, it contributes to an epidemiological study by mapping the spread of MRSA in Brazil, as there is still no monitoring system for these resistant strains or a specific antimicrobial surveillance system in Brazil. Strategies of control and monitoring should be increased in hospital and community environments to avoid the advance of spreading of 
successful clones as well as exporting or importing new strains of MRSA to Brazil.

\section{Conflicts of Interest}

The authors declare that they have no conflicts of interest.

\section{Acknowledgments}

The authors are thankful to Coordenação de Aperfeiçoamento de Pessoal de Nível Superior (CAPES) for the mastering fellowship of Mariana Moreira Andrade.

\section{References}

[1] M. Z. David and R. S. Daum, "Community-associated methicillin-resistant Staphylococcus aureus: epidemiology and clinical consequences of an emerging epidemic," Clinical Microbiology Reviews, vol. 23, no. 3, pp. 616-687, 2010.

[2] M. P. Jevons, ““Celbenin"-resistant staphylococci," BMJ, vol. 1, no. 5219, pp. 124-125, 1961.

[3] R. J. Bulger, "A methicillin-resistant strain of Staphylococcus aureus," Annals of Internal Medicine, vol. 67, no. 1, p. 81, 1967.

[4] F. F. Barrett, R. F. McGehee, and M. Finland, "MethicillinResistant Staphylococcus aureus at boston city hospital," New England Journal of Medicine, vol. 279, no. 9, pp. 441-448, 1968.

[5] R. H. Deurenberg and E. E. Stobberingh, "The evolution of Staphylococcus aureus," Infection, Genetics and Evolution, vol. 8, no. 6, pp. 747-763, 2008.

[6] T. Ito, K. Hiramatsu, D. C. Oliveira et al., "Classification of staphylococcal cassette chromosome mec (SCCmec): guidelines for reporting novel SCCmec elements," Antimicrob Agents Chemother, vol. 53, no. 12, pp. 4961-4967, 2009.

[7] A. P. Johnson, A. Pearson, and G. Duckworth, "Surveillance and epidemiology of MRSA bacteraemia in the UK," Journal of Antimicrobial Chemotherapy, vol. 56, no. 3, pp. 455-462, 2005.

[8] T. Ito, Y. Katayama, and K. Hiramatsu, "Cloning and nucleotide sequence determination of the entire mec DNA of pre-methicillin-resistant Staphylococcus aureus N315," Antimicrobial Agents and Chemotherapy, vol. 43, no. 6, pp. 1449-1458, 1999.

[9] T. Ito, Y. Katayama, K. Asada et al., "Structural comparison of three types of staphylococcal cassette chromosome mec integrated in the chromosome in methicillin-resistant Staphylococcus aureus," Antimicrobial Agents and Chemotherapy, vol. 45, no. 5, pp. 1323-1336, 2001.

[10] S. Lakhundi and K. Zhang, "Methicillin-Resistant Staphylococcus aureus: molecular characterization, evolution, and epidemiology," Clinical Microbiology Reviews, vol. 31, no. 4, pp. 1-103, 2018.

[11] N. Urushibara, M. S. Aung, M. Kawaguchiya, and N. Kobayashi, "Novel staphylococcal cassette chromosome mec (SCCmec) type XIV (5A) and a truncated SCCmec element in SCC composite islands carrying speG in ST5 MRSA in Japan," Journal of Antimicrobial Chemotherapy, vol. 75, no. 1, pp. 46-50, 2019.

[12] J. Liu, D. Chen, B. M. Peters et al., "Staphylococcal chromosomal cassettes mec (SCCmec): a mobile genetic element in methicillin-resistant Staphylococcus aureus," Microbial Pathogenesis, vol. 101, pp. 56-67, 2016.
[13] P. M. N. d. Oliveira, S. N. Buonora, C. L. P. Souza et al., "Surveillance of multidrug-resistant bacteria in pediatric and neonatal intensive care units in Rio de Janeiro State, Brazil," Revista da Sociedade Brasileira de Medicina Tropical, vol. 52, pp. 1-7, 2019.

[14] E. P. L. Pereira Franchi, M. R. N. Barreira, N. de S. L. M. Da Costa et al., "Molecular epidemiology of MRSA in the Brazilian primary health care system," Tropical Medicine \& International Health, vol. 24, no. 3, pp. 339-347, 2018.

[15] Brasil, Plano de Ação Nacional de Prevenção e Controle da Resistência Aos Antimicrobianos No Âmbito da Saúde Única 2018-2022 (PAN-BR), Brasília Ministério da Saúde, Brazil, 2018.

[16] V. S. Anvisa an de, "Programa Nacional de Prevenção e Controle de Gerência Geral de Tecnologia em Serviços de Saúde (PNPCIRAS) 2016-2020,” 2016, http://file://C:/ Users/VAIO/Downloads/PNPCIRAS_2016.pdf.

[17] R. L. B. Ramos, L. A. Teixeira, L. R. Ormonde et al., "Emergence of mupirocin resistance in multiresistant Staphylococcus aureus clinical isolates belonging to Brazilian epidemic clone III::B:A," Journal of Medical Microbiology, vol. 48, no. 3, pp. 303-307, 1999.

[18] A. T. Tresoldi, M. L. M. Branchini, D. d. C. Moreira Filho et al., "Relative frequency of nosocomial microorganisms at unicamp university hospital from 1987 to 1994," Revista do Instituto de Medicina Tropical de São Paulo, vol. 39, no. 6, pp. 333-336, 1997.

[19] M. Dowzicky, G. H. Talbot, C. Feger, P. Prokocimer, J. Etienne, and R. Leclercq, "Characterization of isolates associated with emerging resistance to quinupristin/dalfopristin (Synercid) during a worldwide clinical program," Diagnostic Microbiology and Infectious Disease, vol. 37, no. 1, pp. 57-62, 2000.

[20] K.-T. Luh, P.-R. Hsueh, L.-J. Teng et al., "Quinupristindalfopristin resistance among gram-positive bacteria in Taiwan," Antimicrobial Agents and Chemotherapy, vol. 44, no. 12 , pp. 3374-3380, 2000.

[21] F. M. Marty, W. W. Yeh, C. B. Wennersten et al., "Emergence of a clinical daptomycin-resistant Staphylococcus aureus isolate during treatment of methicillin-resistant Staphylococcus aureus bacteremia and osteomyelitis," Journal of Clinical Microbiology, vol. 44, no. 2, pp. 595-597, 2006.

[22] V. G. Meka, S. K. Pillai, G. Sakoulas et al., "Linezolid resistance in Sequential Staphylococcus aureus Isolates associated with a T2500A mutation in the $23 \mathrm{~S}$ rRNA gene and loss of a single copy of rRNA," The Journal of Infectious Diseases, vol. 190, no. 2, pp. 311-317, 2004.

[23] W. E. Rose and M. J. Rybak, "Tigecycline: first of a new class of antimicrobial agents," Pharmacotherapy, vol. 26, no. 8, pp. 1099-1110, 2006.

[24] P. A. C. Maple, J. M. T. Hamilton-Miller, and W. Brumfitt, "World-wide antibiotic resistance in methicillin-resistant Staphylococcus aureus," The Lancet, vol. 333, no. 8637, pp. 537-540, 1989.

[25] H. F. Chambers and F. R. DeLeo, "Waves of resistance: Staphylococcus aureus in the antibiotic era," Nature Reviews Microbiology, vol. 7, no. 9, pp. 629-641, 2009.

[26] E. Rodríguez-Noriega, C. Seas, M. Guzmán-Blanco et al., "Evolution of methicillin-resistant Staphylococcus aureus clones in Latin America," International Journal of Infectious Diseases, vol. 14, no. 7, pp. e560-e566, 2010.

[27] F. I. S. Freitas, E. Guedes-Stehling, and J. P. Siqueira-Junior, "Resistance to gentamicin and related aminoglycosides in 
Staphylococcus aureus isolated in Brazil," Letters in Applied Microbiology, vol. 29, no. 3, pp. 197-201, 1999.

[28] M. V. D. S. Coimbra, A. M. S. Figueiredo, A. Famiglietti et al., "Spread of the Brazilian epidemic clone of a multiresistant MRSA in two cities in Argentina," Journal of Medical Microbiology, vol. 49, no. 2, pp. 187-192, 2000.

[29] A. M. Vivoni, B. A. Diep, A. C. de Gouveia Magalhaes et al., "Clonal composition of Staphylococcus aureus isolates at a Brazilian university hospital: identification of international circulating lineages," Journal of Clinical Microbiology, vol. 44, no. 5, pp. 1686-1691, 2006.

[30] M. M. Amaral, L. R. Coelho, R. P. Flores et al., "The predominant variant of the Brazilian epidemic clonal complex of methicillin-Resistant Staphylococcus aureus has an enhanced ability to produce biofilm and to adhere to and invade airway epithelial cells," The Journal of Infectious Diseases, vol. 192, no. 5, pp. 801-810, 2005.

[31] H. S. Sader, A. C. Pignatari, R. J. Hollis, and R. N. Jones, "Evaluation of interhospital spread of methicillin-resistant Staphylococcus aureus in Sao paolo, Brazil, using pulsed-field gel electrophoresis of chromosomal DNA," Infection Control \& Hospital Epidemiology, vol. 15, no. 8, p. 508, 1994.

[32] H. S. Sader, A. C. Pignatari, R. J. Hollis, I. Leme, and R. N. Jones, "Oxacillin- and quinolone-resistant Staphylococcus aureus in Sao Paulo, Brazil: a multicenter molecular epidemiology study," Infection Control and Hospital Epidemiology, vol. 14, no. 5, pp. 260-264, 1993.

[33] M. J. S. Soares, N. H. Tokumaru-Miyazaki, A. L. S. Noleto, and A. M. S. Figueired, "Enterotoxin production by Staphylococcus aureus clones and detection of Brazilian epidemic MRSA clone (III::B:A) among isolates from food handlers," Journal of Medical Microbiology, vol. 46, no. 3, pp. 214-221, 1997.

[34] M. H. L. Falcao, L. A. Texeira, B. T. Ferreira-Carvalho, A. A. Borges-Neto, and A. M. S. Figueiredo, "Occurrence of methicillin-resistant and -susceptible Staphylococcus aureus within a single colony contributing to MRSA mis-identification," Journal of Medical Microbiology, vol. 48, no. 6, pp. 515-521, 1999.

[35] M. Nogueira, N. Marinsalta, M. Roussell, and R. Notario, "Importance of hand germ contamination in health-care workers as possible carriers of nosocomial infections," Rev Inst Med Trop Sao Paulo, vol. 43, no. 3, pp. 149-152, 2001.

[36] L. Santos Filho, H. S. Sader, V. I. Bortolotto, P. P. Gontijo Filho, and A. C. Pignatari, "Analysis of the clonal diversity of Staphylococcus aureus methicillin-resistant strains isolated at João Pessoa, state of Paraíba, Brazil," Memórias Do Instituto Oswaldo Cruz, vol. 91, no. 1, pp. 101-105, 1996.

[37] A. L. R. Z. Beretta, P. Trabasso, R. B. Stucchi, and M. L. Moretti, "Use of molecular epidemiology to monitor the nosocomial dissemination of methicillin-resistant Staphylococcus aureus in a University Hospital from 1991 to 2001," Brazilian Journal of Medical and Biological Research, vol. 37, no. 9, pp. 1345-1351, 2004.

[38] J. C. Tórtora, T. L. de Sousa, M. C. Lourenço, and H. R. Lopes, "Nosocomial occurrence of enterotoxigenic multiresistant Staphylococcus strains in Rio de Janeiro," Revista Latinoamericana de Microbiología, vol. 38, no. 1, pp. 1-6, 1996.

[39] L. A. Teixeira, C. A. Resende, L. R. Ormonde et al., "Geographic spread of epidemic multiresistant Staphylococcus aureus clone in Brazil," Journal of Clinical Microbiology, vol. 33, no. 9, pp. 2400-2404, 1995.
[40] I. Mebinda, Z. Quitoco, M. S. Ramundo et al., "First report in South America of companion animal colonization by the USA1100 Clone of Staphylococcus aureus (ST30) and by the European clone of methicillin-resistant Staphylococcus pseudintermedius (ST71)," BMC Research Notes, vol. 27, no. 6, p. 336, 2013.

[41] M. A. de Sousa, I. S. Sanches, M. L. Ferro et al., "Intercontinental spread of a multidrug-resistant methicillin resistant Staphylococcus aureus clone," Journal of Clinical Microbiology, vol. 36, no. 9, pp. 2590-2596, 1998.

[42] M. Aires de Sousa, M. Miragaia, I. Santos Sanches et al., "Three-year assessment of methicillin-resistant Staphylococcus aureus clones in Latin America from 1996 to 1998," Journal of Clinical Microbiology, vol. 39, no. 6, pp. 21972205, 2001.

[43] A. Corso, I. S. Sanches, M. A. De Sousa, A. Rossi, H. De Lencastre, and H. de Lencastre, "Spread of a methicillin-resistant and multiresistant epidemic clone of Staphylococcus aureus in Argentina," Microbial Drug Resistance, vol. 4, no. 4, pp. 277-288, 1998.

[44] M. L. M. Branchini, V. H. Morthland, A. T. Tresoldi, A. Von Nowakonsky, M. B. S. Dias, and M. A. Pfaller, "Application of genomic DNA subtyping by pulsed field gel electrophoresis and restriction enzyme analysis of plasmid DNA to characterize methicillin-resistant Staphylococcus aureus from two nosocomial outbreaks," Diagnostic Microbiology and Infectious Disease, vol. 17, no. 4, pp. 275-281, 1993.

[45] D. C. Oliveira, A. Tomasz, and H. de Lencastre, "The evolution of pandemic clones of methicillin-resistant Staphylococcus aureus: identification of two ancestral genetic backgrounds and the Associated mec elements," Microbial Drug Resistance, vol. 7, no. 4, pp. 349-361, 2001.

[46] D. Oliveira, I. Santos-Sanches, R. Mato et al., "Virtually all methicillin-resistant Staphylococcus aureus (MRSA) infections in the largest Portuguese teaching hospital are caused by two internationally spread multiresistant strains: the "Iberian" and the "Brazilian" clones of MRSA," Clinical Microbiology and Infection, vol. 4, no. 7, pp. 373-384, 1998.

[47] O. P. De Miranda, M. C. Silva-carvalho, A. Ribeiro et al., "Emergence in Brazil of methicillin-resistant Staphylococcus aureus isolates carrying SCC mec IV that are related genetically to the USA800 clone," Clinical Microbiology and Infection, vol. 13, no. 12, pp. 1165-1172, 2007.

[48] M. C. F. Bastos, P. J. J. Mondino, M. L. B. Azevedo, K. R. N. Santos, and M. Giambiagi-deMarval, "Molecular characterization and transfer among Staphylococcus strains of a plasmid conferring high-level resistance to mupirocin," European Journal of Clinical Microbiology \& Infectious Diseases, vol. 18, no. 6, pp. 393-398, 1999.

[49] K. R. N. Santos, L. M. Teixeira, G. S. Leal, L. S. Fonseca, and P. P. Gontijo Filho, "DNA typing of methicillin-resistant Staphylococcus aureus: isolates and factors associated with nosocomial acquisition in two Brazilian university hospitals," Journal of Medical Microbiology, vol. 48, no. 1, pp. 17-23, 1999.

[50] K. R. N. dos Santos, L. de Souza Fonseca, and P. P. G. Filho, "Emergence of high-level mupirocin resistance in methicillin-resistant Staphylococcus aureus isolated from Brazilian university hospitals," Infection Control and Hospital Epidemiology, vol. 17, no. 12, pp. 813-816, 1996.

[51] G. P. Korn, M. D. V. Martino, I. M. Mimica, L. J. Mimica, P. A. Chiavone, and L. R. d. S. Musolino, "High frequency of colonization and absence of identifiable risk factors for methicillin-resistant Staphylococcus aureus (MRSA) in 
intensive care units in Brazil," Brazilian Journal of Infectious Diseases, vol. 5, no. 1, pp. 1-7, 2001.

[52] G. Sadoyama and P. P. Gontijo Filho, "Risk factors for methicillin resistant and sensitive Staphylococcus aureus infection in a Brazilian university hospital," The Brazilian Journal of Infectious Diseases, vol. 4, no. 3, pp. 135-143, 2000.

[53] B. A. d. Moraes, C. A. N. Cravo, M. M. Loureiro, C. A. Solari, and M. D. Asensi, "Epidemiological analysis of bacterial strains involved in hospital infection in a university hospital from Brazil," Revista do Instituto de Medicina Tropical de São Paulo, vol. 42, no. 4, pp. 201-207, 2000.

[54] M. Loureiro, B. d. Moraes, M. Quadra, G. Pinheiro, P. Suffys, and M. Asensi, "Molecular epidemiology of methicillin resistant Staphylococcus aureus isolated from newborns in a hospital in Rio de Janeiro, Brazil," Memórias Do Instituto Oswaldo Cruz, vol. 95, no. 6, pp. 777-782, 2000.

[55] V. C. Pereira, D. F. M. Riboli, M. d. L. R. d. S. da Cunha, and S. LR de, "Characterization of the clonal profile of MRSA isolated in neonatal and pediatric intensive care units of a University Hospital," Annals of Clinical Microbiology and Antimicrobials, vol. 13, no. 1, pp. 1-6, 2014.

[56] L. A. Teixeira, M. C. S. Lourenço, and A. M. S. Figueiredo, "Emergence of a methicillin-resistant Staphylococcus aureus clone related to the Brazilian epidemic clone III::B:A causing invasive disease among AIDS patients in a Brazilian hospital," Microbial Drug Resistance, vol. 2, no. 4, pp. 393-399, 1996.

[57] M. J. D. S. Soares, L. A. Teixeira, M. D. R. Nunes, M. C. D. S. Carvalho, B. T. Ferreira-Carvalho, and A. M. S. Figueiredo, "Analysis of different molecular methods for typing methicillin-resistant Staphylococcus aureus isolates belonging to the Brazilian epidemic clone," Journal of Medical Microbiology, vol. 50, no. 8, pp. 732-742, 2001.

[58] M. J. dos Santos Soares, M. C. da Silva-Carvalho, B. T. Ferreira-Carvalho, and A. M. S. Figueiredo, "Spread of methicillin-resistant Staphylococcus aureus belonging to the Brazilian epidemic clone in a general hospital and emergence of heterogenous resistance to glycopeptide antibiotics among these isolates," Journal of Hospital Infection, vol. 44, no. 4, pp. 301-308, 2000.

[59] C. Reinert, J. A. McCulloch, S. Watanabe, T. Ito, K. Hiramatsu, and E. M. Mamizuka, "Type IV SCCmec found in decade old Brazilian MRSA isolates," Brazilian Journal of Infectious Diseases, vol. 12, no. 3, pp. 1995-1998, 2008.

[60] C. Brites, N. Silva, and M. Sampaio- Sá, “Temporal evolution of the prevalence of methicillin-resistant Staphylococcus aureus in a tertiary hospital in Bahia, Brazil: a nine-year evaluation study," Brazilian Journal of Infectious Diseases, vol. 10, no. 4, pp. 235-238, 2006.

[61] L. R. R. Perez and P. A. D'azevedo, "Clonal types and antimicrobial resistance profiles of methicillin-resistant Staphylococcus aureus isolates from hospitals in south Brazil," Revista do Instituto de Medicina Tropical de São Paulo, vol. 50, no. 3, pp. 135-137, 2008.

[62] A. Martins, D. F. Moraes Riboli, D. F. Moraes Riboli, and V. Cataneli Pereira, "Molecular characterization of methicillin-resistant Staphylococcus aureus isolated from a Brazilian university hospital," The Brazilian Journal of Infectious Diseases, vol. 18, no. 3, pp. 331-335, 2014.

[63] M. V. P. Rodrigues, C. M. C. Branco Fortaleza, C. S. Martins Souza, N. B. Teixeira, and M. d. L. Ribeiro de Souza da Cunha, "Genetic determinants of methicillin resistance and virulence among Staphylococcus aureus isolates recovered from clinical and surveillance cultures in a Brazilian teaching hospital," ISRN Microbiology, vol. 2012, no. 975143, pp. 1-4, 2012.

[64] M. C. N. Melo, M. C. Silva-Carvalho, R. L. Ferreira et al., "Detection and molecular characterization of a gentamicinsusceptible, methicillin-resistant Staphylococcus aureus (MRSA) clone in Rio de Janeiro that resembles the New York/Japanese clone," Journal of Hospital Infection, vol. 58, no. 4, pp. 276-285, 2004.

[65] R. M. F. Caboclo, F. S. Cavalcante, N. L. P. Iorio et al., "Methicillin-resistant Staphylococcus aureus in Rio de Janeiro hospitals: dissemination of the USA400/ST1 and USA800/ST5 SCCmec type IV and USA100/ST5 SCCmec type II lineages in a public institution and polyclonal presence in a private one," American Journal of Infection Control, vol. 41, no. 3, pp. e21-e26, 2013.

[66] R. Rozenbaum, M. C. Silva-Carvalho, R. R. Souza et al., "Molecular characterization of methicillin-resistant Staphylococcus aureus disseminated in a home care system," Infection Control \& Hospital Epidemiology, vol. 27, no. 10, pp. 1041-1050, 2006.

[67] A. N. G. Dabul and I. L. B. C. Camargo, "Molecular characterization of methicillin-resistant Staphylococcus aureus resistant to tigecycline and daptomycin isolated in a hospital in Brazil," Epidemiology and Infection, vol. 142, no. 3, pp. 479-483, 2014.

[68] D. C. Oliveira, A. Tomasz, and H. de Lencastre, "Secrets of success of a human pathogen: molecular evolution of pandemic clones of meticillin-resistant Staphylococcus aureus," The Lancet Infectious Diseases, vol. 2, no. 3, pp. 180-189, 2002.

[69] A. P. Becker, O. Santos, F. M. Castrucci, C. Dias, and P. A. D'azevedo, "First report of methicillin-resistant Staphylococcus aureus cordobes/chilean clone involved in nosocomial infections in Brazil," Epidemiology and Infection, vol. 140, no. 8, pp. 1372-1375, 2012.

[70] J. Lamaro-cardoso, H. de Lencastre, A. Kipnis et al., "Molecular epidemiology and risk factors for nasal carriage of Staphylococcus aureus and methicillin-resistant S. aureus in infants attending day care centers in Brazil," Journal of Clinical Microbiology, vol. 47, no. 12, pp. 3991-3997, 2009.

[71] M. F. Bonesso, S. A. Marques, C. H. Camargo, C. M. C. B. Fortaleza, and M. d. L. R. d. S. d. Cunha, "Community-associated methicillin-resistant Staphylococcus aureus in non-outbreak skin infections," Brazilian Journal of Microbiology, vol. 45, no. 4, pp. 1401-1407, 2014.

[72] M. S. Carmo, F. Inoue, S. S. Andrade et al., "New multilocus sequence typing of MRSA in São Paulo, Brazil," Brazilian Journal of Medical and Biological Research, vol. 44, no. 10, pp. 1013-1017, 2011.

[73] R. C. Chamon, S. d. S. Ribeiro, T. M. da Costa, S. A. Nouér, and K. R. N. dos Santos, "Complete substitution of the Brazilian endemic clone by other methicillin-resistant Staphylococcus aureus lineages in two public hospitals in Rio de Janeiro, Brazil," The Brazilian Journal of Infectious Diseases, vol. 21, no. 2, pp. 185-189, 2017.

[74] E. Rodríguez-Noriega and C. Seas, "The changing pattern of methicillin-resistant Staphylococcus aureus clones in Latin America: implications for clinical practice in the region," Brazilian Journal of Infectious Diseases, vol. 14, no. 2, pp. 87-96, 2010.

[75] P. d. A. Trindade, R. L. Pacheco, S. F. Costa et al., "Prevalence of SCCmec type IV in nosocomial bloodstream isolates of 
methicillin-resistant Staphylococcus aureus," Journal of Clinical Microbiology, vol. 43, no. 7, pp. 3435-3437, 2005.

[76] M. A. Vieira, R. Minamisava, V. Pessoa-Júnior et al., "Methicillin-resistant Staphylococcus aureus nasal carriage in neonates and children attending a pediatric outpatient clinics in Brazil," The Brazilian Journal of Infectious Diseases, vol. 18, no. 1, pp. 42-47, 2014.

[77] K. A. Prates, A. M. Torres, L. B. Garcia, S. F. Ogatta, C. L. Cardoso, and M. C. Bronharo Tognim, "Nasal carriage of methicillin-resistant Staphylococcus aureus in university students," The Brazilian Journal of Infectious Diseases, vol. 14, no. 3, pp. 316-318, 2010.

[78] E. E. Yamada Ogatta, "Genetic analysis of community isolates of Staphylococcus aureus in Western," Journal of Hospital Infection, vol. 25, no. 2, pp. 97-108, 1993.

[79] G. R. Nimmo and G. W. Coombs, "Community-associated methicillin-resistant Staphylococcus aureus (MRSA) in Australia," International Journal of Antimicrobial Agents, vol. 31, no. 5, pp. 401-410, 2008.

[80] A. Ribeiro, C. Dias, M. C. Silva-carvalho et al., "First report of infection with community-acquired methicillin-resistant Staphylococcus aureus in south America," Journal of Clinical Microbiology, vol. 43, no. 4, pp. 1985-1988, 2005.

[81] J. M. Egido and M. L. Barros, "Preliminary study of community-acquired Staphylococcus aureus infection in manaus hospital, amazonia region, Brazil," Revista da Sociedade Brasileira de Medicina Tropical, vol. 36, no. 6, pp. 707-709, 2003.

[82] F. Razera, S. D. Stefani, R. R. Bonamigo, G. S. Olm, C. A. G. Dias, and G. A. Narvaez, "CA-MRSA em furunculose: relato de caso do sul do Brasil," Anais Brasileiros de Dermatologia, vol. 84, no. 5, pp. 515-518, 2009.

[83] A. Ribeiro, A. Z. Coronado, M. C. Silva-carvalho et al., "Detection and characterization of international community-acquired infections by methicillin-resistant Staphylococcus aureus clones in Rio de Janeiro and Porto Alegre cities causing both community- and hospital-associated diseases," Diagnostic Microbiology and Infectious Disease, vol. 59, no. 3, pp. 339-345, 2007.

[84] Â. G. de Vasconcellos, R. D. Leal, A. Silvany-Neto, and C. M. Nascimento-Carvalho, "Oxacillin or cefalotin treatment of hospitalized children with cellulitis," Japanese Journal of Infectious Diseases, vol. 65, no. 1, pp. 7-12, 2012.

[85] M. E. Vola, A. S. Moriyama, R. Lisboa et al., "Prevalence and antibiotic susceptibility of methicillin-resistant Staphylococcus aureus in ocular infections," Arquivos Brasileiros de Oftalmologia, vol. 76, no. 6, pp. 350-353, 2013.

[86] C. Q. Fortes, C. A. Espanha, F. P. Bustorff et al., "First reported case of infective endocarditis caused by communityacquired methicillin-resistant Staphylococcus aureus not associated with healthcare contact in Brazil," Brazilian Journal of Infectious Diseases, vol. 12, no. 6, pp. 541-543, 2008.

[87] B. E. S. de Araújo, J. M. Borchert, P. G. Manhães et al., “A rare case of pyomyositis complicated by compartment syndrome caused by ST30-staphylococcal cassette chromosome mec type IV methicillin-resistant Staphylococcus aureus," The American Journal of Emergency Medicine, vol. 28, no. 4, pp. e3-e537, 2010.

[88] L. C. Gelatti, T. Sukiennik, A. P. Becker et al., "Sepse por Staphylococus aureus resistente à meticilina adquirida na comunidade no sul do Brasil," Revista da Sociedade Brasileira de Medicina Tropical, vol. 42, no. 4, pp. 458-460, 2009.
[89] L. C. Gelatti, R. R. Bonamigo, F. M. Inoue et al., "Community-acquired methicillin-resistant Staphylococcus aureus carrying SCCmec type IV in southern Brazil," Revista da Sociedade Brasileira de Medicina Tropical, vol. 46, no. 1, pp. 34-38, 2013.

[90] R. Rozenbaum, M. G. Sampaio, G. S. Batista et al., "The first report in Brazil of severe infection caused by communityacquired methicillin-resistant Staphylococcus aureus (CAMRSA)," Brazilian Journal of Medical and Biological Research, vol. 42, no. 8, pp. 756-760, 2009.

[91] T. Brust, T. M. d. Costa, J. C. Amorim, M. D. Asensi, O. Fernandes, and F. Aguiar-Alves, "Hospital-associated methicillin-resistant Staphylococcus aureus carrying the PVL gene outbreak in a Public Hospital in Rio de Janeiro, Brazil," Brazilian Journal of Microbiology, vol. 44, no. 3, pp. 865-868, 2013.

[92] R. R. Souza, L. R. Coelho, A. M. N. Botelho et al., "Biofilm formation and prevalence of lukF-pv, seb, sec and tst genes among hospital- and community-acquired isolates of some international methicillin-resistant Staphylococcus aureus lineages," Clinical Microbiology and Infection, vol. 15, no. 2, pp. 203-207, 2009.

[93] C. P. Garcia, J. F. Rosa, M. A. Cursino et al., "Non-multidrug-resistant, methicillin-resistant Staphylococcus aureus in a neonatal unit," The Pediatric Infectious Disease Journal, vol. 33, no. 10, pp. e252-e259, 2014.

[94] J. Lamaro-cardoso, M. Castanheira, R. M. de Oliveira et al., "Carriage of methicillin-resistant Staphylococcus aureus in children in Brazil," Diagnostic Microbiology and Infectious Disease, vol. 57, no. 4, pp. 467-470, 2007.

[95] F. A. Ferreira, R. R. Souza, R. R. Bonelli, M. A. Américo, S. E. L. Fracalanzza, and A. M. S. Figueiredo, "Comparison of in vitro and in vivo systems to study ica-independent Staphylococcus aureus biofilms," Journal of Microbiological Methods, vol. 88, no. 3, pp. 393-398, 2012.

[96] M. C. Silva-Carvalho, R. R. Bonelli, R. R. Souza et al., "Emergence of multiresistant variants of the communityacquired methicillin-resistant Staphylococcus aureus lineage ST1-SCCmecIV in 2 hospitals in Rio de Janeiro, Brazil," Diagnostic Microbiology and Infectious Disease, vol. 65, no. 3, pp. 300-305, 2009.

[97] G. G. Cury, C. Mobilon, E. G. Stehling et al., "Molecular typing of methicillin-resistant Staphylococcus aureus (MRSA) strains isolated in two metropolitan areas of São Paulo State, southeast Brazil," Brazilian Journal of Infectious Diseases, vol. 13, no. 3, pp. 165-169, 2009.

[98] L. V. Scribel, M. C. Silva-Carvalho, R. R. Souza et al., "Clinical and molecular epidemiology of methicillin-resistant Staphylococcus aureus carrying SCCmecIV in a university hospital in Porto Alegre, Brazil," Diagnostic Microbiology and Infectious Disease, vol. 65, no. 4, pp. 457-461, 2009.

[99] R. P. Schuenck, S. A. Nouér, C. de Oliveira Winter et al., "Polyclonal presence of non-multiresistant methicillin-resistant Staphylococcus aureus isolates carrying SCCmec IV in health care-associated infections in a hospital in Rio de Janeiro, Brazil," Diagnostic Microbiology and Infectious Disease, vol. 64, no. 4, pp. 434-441, 2009.

[100] C. O. Beltrame, A. M. N. Botelho, M. C. Silva-Carvalho et al., "Restriction modification (RM) tests associated to additional molecular markers for screening prevalent MRSA clones in Brazil," European Journal of Clinical Microbiology \& Infectious Diseases, vol. 31, no. 8, pp. 2011-2016, 2012. 
[101] M. V. P. Rodrigues, C. M. C. B. Fortaleza, D. F. M. Riboli, R. S. Rocha, C. Rocha, and M. d. L. R. d. S. d. Cunha, "Molecular epidemiology of methicillin-resistant Staphylococcus aureus in a burn unit from Brazil," Burns, vol. 39, no. 6, pp. 1242-1249, 2013.

[102] G. B. Campos, S. G. Souza, T. N. Lob O et al., "Isolation, molecular characteristics and disinfection of methicillinresistant Staphylococcus aureus from ICU units in Brazil," The New Microbiologica, vol. 35, no. 2, pp. 183-190, 2012.

[103] F. S. Cavalcante, M. V. Pinheiro, D. d. C. Ferreira et al., "Characteristics of methicillin-resistant Staphylococcus aureus in patients on admission to a teaching hospital in Rio de Janeiro, Brazil," American Journal of Infection Control, vol. 45, no. 11, pp. 1190-1193, 2017.

[104] C. F. d. Oliveira, A. T. Morey, J. P. Santos et al., "Molecular and phenotypic characteristics of methicillin-resistant Staphylococcus aureus isolated from hospitalized patients," The Journal of Infection in Developing Countries, vol. 9, no. 7, pp. 743-751, 2015.

[105] F. C. Duarte, E. R. Tavares, T. Danelli et al., "Disseminated clonal complex 5 (CC5) methicillin-resistant Staphylococcus aureus SCCmec type ii in a tertiary hospital of southern Brazil," Revista do Instituto de Medicina Tropical de São Paulo, vol. 60, pp. 5-9, 2018.

[106] L. M. de Oliveira, I. M. Van Der Heijden, G. R. Golding et al., "Staphylococcus aureus isolates colonizing and infecting cirrhotic and liver-transplantation patients: comparison of molecular typing and virulence factors," BMC Microbiology, vol. 15, no. 1, pp. 1-9, 2015.

[107] I. M. Van Der Heijden, L. M. de Oliveira, G. C. Brito et al., "Virulence and resistance profiles of MRSA isolates in preand post-liver transplantation patients using microarray," Journal of Medical Microbiology, vol. 65, no. 10, pp. 10601073, 2016.

[108] M. da Silveira, M. d. L. R. d. S. da Cunha, S. LR de, C. S. M. de Souza, A. A. F. Correa, and C. M. C. B. Fortaleza, "Nasal colonization with methicillin-resistant Staphylococcus aureus among elderly living in nursing homes in Brazil: risk factors and molecular epidemiology," Annals of Clinical Microbiology and Antimicrobials, vol. 17, no. 1, pp. 1-5, 2018.

[109] H. H. Caiaffa-filho, P. A. Trindade, P. Gabriela da Cunha et al., "Methicillin-resistant Staphylococcus aureus carrying SCCmec type II was more frequent than the Brazilian endemic clone as a cause of nosocomial bacteremia," Diagnostic Microbiology and Infectious Disease, vol. 76, no. 4, pp. 518-520, 2013.

[110] J. A. McCulloch, A. C. d. O. Silveira, A. d. C. Lima Moraes et al., "Complete genome sequence of Staphylococcus aureus FCFHV36, a methicillin-resistant strain heterogeneously resistant to vancomycin," Genome Announcements, vol. 3, no. 4, pp. 4-5, 2015.

[111] F. Rossi, L. Diaz, A. Wollam et al., "Transferable vancomycin resistance in a community-associated MRSA lineage," New England Journal of Medicine, vol. 370, no. 16, pp. 1524-1531, 2014.

[112] F. A. Ferreira, R. R. Souza, B. de Sousa Moraes et al., "Impact of agr dysfunction on virulence profiles and infections associated with a novel methicillin-resistant Staphylococcus aureus (MRSA) variant of the lineage ST1-SCCmec IV," BMC Microbiology, vol. 13, no. 1, pp. 93-12, 2013.

[113] M. A. Guimarães, M. S. Ramundo, M. A. Américo et al., "A comparison of virulence patterns and in vivo fitness between hospital- and community-acquired methicillin-resistant Staphylococcus aureus related to the USA400 clone,"
European Journal of Clinical Microbiology \& Infectious Diseases, vol. 34, no. 3, pp. 497-509, 2015.

[114] S. P. d. Carvalho, J. B. d. Almeida, Y. M. F. S. Andrade et al., "Community-acquired methicillin-resistant Staphylococcus aureus carrying SCC mec type IV and V isolated from healthy children attending public daycares in northeastern Brazil," The Brazilian Journal of Infectious Diseases, vol. 21, no. 4, pp. 464-467, 2017.

[115] D. F. Lima, N. B. V. Brazão, T. W. Folescu et al., "PantonValentine leukocidin (PVL) gene carriage among Staphylococcus aureus strains with SCCmec types I, III, IV, and V recovered from cystic fibrosis pediatric patients in Brazil," Diagnostic Microbiology and Infectious Disease, vol. 78, no. 1, pp. 59-62, 2014.

[116] A. V. P. Zuma, D. F. Lima, A. P. D. A. C. Assef, E. A. Marques, and R. S. Leão, "Molecular characterization of methicillin-resistant Staphylococcus aureus isolated from blood in Rio de Janeiro displaying susceptibility profiles to non- $\beta$-lactam antibiotics," Brazilian Journal of Microbiology, vol. 48, no. 2, pp. 237-241, 2017.

[117] A. C. O. Silveira, G. R. Cunha, J. Caierão, C. M. de Cordova, and P. A. d'Azevedo, "MRSA from Santa Catarina State, Southern Brazil: intriguing epidemiological differences compared to other Brazilian regions," The Brazilian Journal of Infectious Diseases, vol. 19, no. 4, pp. 384-389, 2015.

[118] C. R. P. Soares, C. R. de Lira, M. A. H. Cunha et al., "Prevalence of nasal colonization by methicillin-resistant Staphylococcus aureus in outpatients living with HIV/AIDS in a Referential Hospital of the Northeast of Brazil," BMC Research Notes, vol. 11, no. 794, pp. 1-7, 2018.

[119] R. C. Zanella, M. C. d. C. Brandileone, S. C. G. Almeida et al., "Nasopharyngeal carriage of Streptococcus pneumoniae, Haemophilus influenzae, and Staphylococcus aureus in a Brazilian elderly cohort," PLoS One, vol. 14, no. 8, Article ID e0221525, 2019.

[120] L. A. Devriese, L. R. Damme, and L. Fameree, "Methicillin (Cloxacillin)-Resistant Staphylococcus aureus strains isolated from bovine mastitis cases," Zentralblatt für Veterinärmedizin Reihe B, vol. 19, no. 7, pp. 598-605, 1972.

[121] M. M. L. Van Rijen, P. H. Van Keulen, and J. A. Kluytmans, "Increase in a Dutch hospital of methicillin-resistant Staphylococcus aureus related to animal farming," Clinical Infectious Diseases, vol. 46, no. 2, pp. 261-263, 2008.

[122] X. W. Huijsdens, B. J. v. Dijke, E. Spalburg et al., "Community-acquired MRSA and pig-farming," Annals of Clinical Microbiology and Antimicrobials, vol. 5, no. 26, pp. 1-4, 2006.

[123] L. Armand-Lefevre, R. Ruimy, and A. Andremont, "Clonal comparison of Staphylococcus aureus isolates from healthy pig farmers, human controls, and pigs," Emerging Infectious Diseases, vol. 11, no. 5, pp. 711-714, 2005.

[124] D. F. Lima, R. W. Cohen, G. A. Rocha, R. M. Albano, E. A. Marques, and R. S. Leão, "Genomic information on multidrug-resistant livestock-associated methicillin-resistant Staphylococcus aureus ST398 isolated from a Brazilian patient with cystic fibrosis," Memórias Do Instituto Oswaldo Cruz, vol. 112, no. 1, pp. 79-80, 2017.

[125] E. D. A. Neto, R. F. A. Pereira, R. E. Snyder et al., "Emergence of methicillin-resistant Staphylococcus aureus from clonal complex 398 with no livestock association in Brazil," Memórias Do Instituto Oswaldo Cruz, vol. 112, no. 9, pp. 647-649, 2017.

[126] D. J. Diekema, M. A. Pfaller, D. Shortridge, M. Zervos, and R. N. Jones, "Twenty-year trends in antimicrobial susceptibilities among Staphylococcus aureus from the SENTRY 
antimicrobial surveillance program," Open Forum Infectious Diseases, vol. 6, no. 1, pp. S47-S53, 2019.

[127] M. C. Perim, J. d. C. Borges, S. R. C. Celeste et al., "Aerobic bacterial profile and antibiotic resistance in patients with diabetic foot infections," Revista da Sociedade Brasileira de Medicina Tropical, vol. 48, no. 5, pp. 546-554, 2015.

[128] H. M. Barreto, F. C. Fontinele, A. P. De Oliveira et al., "Phytochemical prospection and modulation of antibiotic activity in vitro by lippia origanoides H. B. K. in methicillin resistant Staphylococcus aureus," BioMed Research International, vol. 2014, Article ID 305610, 7 pages, 2014.

[129] D. A. M. Assis, R. P. Rezende, and J. C. T. Dias, "Use of metagenomics and isolation of actinobacteria in Brazil's atlantic rainforest soil for antimicrobial prospecting," ISRN Biotechnology, vol. 2014, pp. 1-7, 2014.

[130] R. T. Gomes, T. G. Lyra, N. N. Alves, R. M. Caldas, M.-G. Barberino, and C. M. Nascimento-Carvalho, "Methicillin-resistant and methicillin-susceptible community-acquired Staphylococcus aureus infection among children," The Brazilian Journal of Infectious Diseases, vol. 17, no. 5, pp. 573-578, 2013.

[131] C. M. Nascimento-carvalho, T. G. Lyra, N. N. Alves, R. M. Caldas, and M. G. Barberino, "Resistance to methicillin and other antimicrobials among community-acquired and nosocomial Staphylococcus aureus strains in a pediatric teaching hospital in salvador, northeast Brazil," Microbial Drug Resistance, vol. 14, no. 2, pp. 129-131, 2008.

[132] V. A. Paixão, T. F. Barros, C. M. C. Mota, T. F. Moreira, M. A. Santana, and J. N. Reis, "Prevalence and antimicrobial susceptibility of respiratory pathogens in patients with cystic fibrosis," Brazilian Journal of Infectious Diseases, vol. 14, no. 4, pp. 406-409, 2006.

[133] S. P. de Carvalho, J. B. de Almeida, Y. M. F. S. Andrade et al., "Molecular characteristics of methicillin-resistant Staphylococcus aureus isolates from hospital and community environments in northeastern Brazil," The Brazilian Journal of Infectious Diseases, vol. 23, no. 2, pp. 134-138, 2019.

[134] G. C. M. Almeida, M. M. dos Santos, N. G. M. Lima, T. A. Cidral, M. C. N. Melo, and K. C. Lima, "Prevalence and factors associated with wound colonization by Staphylococcus spp. and Staphylococcus aureus in hospitalized patients in inland northeastern Brazil: a cross-sectional study," BMC Infectious Diseases, vol. 14, no. 1, pp. 1-8, 2014.

[135] F. R. Novak, A. V. da Silva, A. M. S. Figueiredo, and A. N. Hagler, "Contamination of expressed human breast milk with an epidemic multiresistant Staphylococcus aureus clone," Journal of Medical Microbiology, vol. 49, no. 12, pp. 1109-1117, 2000.

[136] F. Novak, J. Almeida, M. Warnken, B. Ferreira-Carvalho, and A. Hagler, "Methicillin-resistant Staphylococcus aureus in human milk," Memórias Do Instituto Oswaldo Cruz, vol. 95, no. 1, pp. 29-33, 2000.

[137] F. C. d. Sousa-Júnior, M. C. Silva-Carvalho, M. J. B. C. Fernandes et al., "Genotyping of methicillinresistant Staphylococcus aureus isolates obtained in the Northeast region of Brazil," Brazilian Journal of Medical and Biological Research, vol. 42, no. 10, pp. 877-881, 2009.

[138] F. C. de Sousa, É. D. F. Nunes, E. D. do Nascimento, S. M. de Oliveira, M. C. N. de Melo, and M. J. d. B. C. Fernandes, "Prevalência de Staphylococcus spp resistentes à meticilina isolados em uma maternidade escola da Cidade de Natal, Estado do Rio Grande do Norte," Revista da Sociedade Brasileira de Medicina Tropical, vol. 42, no. 2, pp. 179-182, 2009.
[139] F. C. d. Sousa Júnior, G. d. S. Néri, A. K. Silva et al., "Evaluation of different methods for detecting methicillin resistance in Staphylococcus aureus isolates in a university hospital located in the northeast of Brazil," Brazilian Journal of Microbiology, vol. 41, no. 2, pp. 316-320, 2010.

[140] D. M. d. S. Oliveira, D. F. R. d. Andrade, A. R. d. S. Ibiapina et al., "High rates of methicillin-resistant Staphylococcus aureus colonisation in a Brazilian intensive care unit," Intensive and Critical Care Nursing, vol. 49, pp. 51-57, 2018.

[141] E. C. B. F. d. Silva, M. d. G. C. Antas, A. M. B. Neto, F. L. d. Melo, M. A. V. de Melo, and M. A. V. Maciel, "Prevalence and risk factors for Staphylococcus aureus in health care workers at a University Hospital of Recife-PE," Brazilian Journal of Infectious Diseases, vol. 12, no. 6, pp. 504-508, 2008.

[142] S. M. M. Cavalcanti, E. R. d. França, C. Cabral et al., "Prevalence of Staphylococcus aureus introduced into intensive care units of a university hospital," Brazilian Journal of Infectious Diseases, vol. 9, no. 1, pp. 56-63, 2005.

[143] F. B. Caraciolo, M. A. V. Maciel, J. B. d. Santos, M. A. Rabelo, and V. Magalhães, "Antimicrobial resistance profile of Staphylococcus aureus isolates obtained from skin and soft tissue infections of outpatients from a university hospital in Recife -PE, Brazil," Anais Brasileiros de Dermatologia, vol. 87, no. 6, pp. 857-861, 2012.

[144] M. A. Rabelo, A. M. Bezerra Neto, S. O. Loibman et al., "The occurrence and dissemination of methicillin and vancomycin-resistant Staphylococcus in samples from patients and health professionals of a university hospital in recife, State of Pernambuco, Brazil," Revista da Sociedade Brasileira de Medicina Tropical, vol. 47, no. 4, pp. 437-446, 2014.

[145] J. N. d. P. Pereira, M. A. Rabelo, J. L. d. C. Lima, A. M. B. Neto, A. C. d. S. Lopes, and M. A. V. Maciel, "Phenotypic and molecular characterization of resistance to macrolides, lincosamides and type B streptogramin of clinical isolates of Staphylococcus spp. of a university hospital in Recife, Pernambuco, Brazil," The Brazilian Journal of Infectious Diseases, vol. 20, no. 3, pp. 276-281, 2016.

[146] L. C. Gelatti, R. R. Bonamigo, A. P. Becker, L. M. Eidt, L. Ganassini, and P. A. d' Azevedo, "Phenotypic, molecular and antimicrobial susceptibility assessment in isolates from chronic ulcers of cured leprosy patients: a case study in Southern Brazil," Anais Brasileiros de Dermatologia, vol. 89, no. 3, pp. 404-408, 2014.

[147] J. P. M. Senna, C. A. Pinto, S. Mateos, A. Quintana, and D. S. Santos, "Spread of a dominant methicillin-resistant Staphylococcus aureus (MRSA) clone between Uruguayan and South of Brazil Hospitals," Journal of Hospital Infection, vol. 53, no. 2, pp. 156-157, 2003.

[148] A. M. Sandri, M. G. Dalarosa, L. R. d. Alcântara, L. d. S. Elias, and A. P. Zavascki, "Reduction in inddence of nosocomial methicillin-resistant Staphylococcus aureus (MRSA) infection in an intensive care unit: role of treatment with mupirocin ointment and chlorhexidine baths for nasal carriers of MRSA," Infection Control \& Hospital Epidemiology, vol. 27, no. 2, pp. 185-187, 2006.

[149] J. P. M. Senna, C. A. Pinto, D. R. Bernardon et al., "Identification of methicillin-resistant Staphylococcus aureus among care-workers and patients in an emergency hospital," Journal of Hospital Infection, vol. 54, no. 2, pp. 165-167, 2003.

[150] H. B. Santos, D. P. Machado, S. A. Camey, R. S. Kuchenbecker, A. L. Barth, and M. B. Wagner, "Prevalence and acquisition of MRSA amongst patients 
admitted to a tertiary-care hospital in Brazil," BMC Infectious Diseases, vol. 10, no. 1, p. 328, 2010.

[151] R. Salomao, V. D. Rosenthal, G. Grimberg et al., "Deviceassociated infection rates in intensive care units of Brazilian hospitals: datos de la Comunidad Científica Internacional de Control de Infecciones Nosocomiales," Revista Panamericana de Salud Pública, vol. 24, no. 3, pp. 195-202, 2008.

[152] K. C. Reiter, A. B. M. P. Machado, A. L. P. d. Freitas, A. L. Barth, P. De Freitas, and A. L. Barth, "High prevalence of methicillin-resistant Staphylococcus aureus with SCCmec type III in cystic fibrosis patients in southern, Brazil," Revista da Sociedade Brasileira de Medicina Tropical, vol. 43, no. 4, pp. 377-381, 2010.

[153] T. S. Jacoby, R. S. Kuchenbecker, R. P. dos Santos, L. Magedanz, P. Guzatto, and L. B. Moreira, "Impact of hospital-wide infection rate, invasive procedures use and antimicrobial consumption on bacterial resistance inside an intensive care unit," Journal of Hospital Infection, vol. 75, no. 1, pp. 23-27, 2010.

[154] A. C. Gales, H. S. Sader, J. Ribeiro, C. Zoccoli, A. Barth, and A. C. Pignatari, "Antimicrobial susceptibility of gram-positive bacteria isolated in brazilian hospitals participating in the SENTRY Program (2005-2008)," Brazilian Journal of Infectious Diseases, vol. 13, no. 2, pp. 90-98, 2009.

[155] R. Seligman, L. F. Ramos-Lima, V. d. A. Oliveira, C. Sanvicente, J. Sartori, and E. F. Pacheco, "Risk factors for infection with multidrug-resistant bacteria in non-ventilated patients with hospital-acquired pneumonia," Jornal Brasileiro de Pneumologia, vol. 39, no. 3, pp. 339-348, 2013.

[156] L. R. R. Perez, A. L. S. Antunes, J. W. Bonfanti et al., "Detection of methicillin-resistant Staphylococcus aureus in clinical specimens from cystic fibrosis patients by use of chromogenic selective agar," Journal of Clinical Microbiology, vol. 50, no. 7, pp. 2506-2508, 2012.

[157] D. P. Machado, L. Z. Goldani, R. M. Paiva et al., "The impact of serum vancomycin levels and minimum inhibitory concentrations of methicillin-resistant Staphylococcus aureus on mortality in patients with nosocomial pneumonia," Canadian Journal of Infectious Diseases and Medical Microbiology, vol. 24, no. 3, p. e75, 2013.

[158] A. Cechinel, D. P. Machado, E. Turra et al., "Association between accessory gene regulator polymorphism and mortality among critically ill patients receiving vancomycin for nosocomial MRSA bacteremia: a cohort study," Canadian Journal of Infectious Diseases and Medical Microbiology, vol. 2016, Article ID 8163456, 5 pages, 2016.

[159] F. C. P. Rossatto, L. A. Proença, A. P. Becker, A. C. d. O. Silveira, J. Caierão, and P. A. D’azevedo, "Evaluation of methods in detecting vancomycin MIC among MRSA isolates and the changes in accuracy related to different MIC values," Revista do Instituto de Medicina Tropical de São Paulo, vol. 56, no. 6, pp. 469-472, 2014.

[160] A. Bottega, M. d. A. Rodrigues, F. A. Carvalho et al., "Evaluation of constitutive and inducible resistance to clindamycin in clinical samples of Staphylococcus aureus from a tertiary hospital," Revista da Sociedade Brasileira de Medicina Tropical, vol. 47, no. 5, pp. 589-592, 2014.

[161] C. R. Busato, J. Gabardo, and M. T. C. Leão, "The evolution of the resistance of Staphylococcus aureus found on healthcare workers correlated with local consumption of antibiotics," Brazilian Journal of Infectious Diseases, vol. 10, no. 3, pp. 185-190, 2006.

[162] F. C. Duarte, T. Danelli, E. R. Tavares et al., "Fatal sepsis caused by mecA-positive oxacillin-susceptible
Staphylococcus aureus: first report in a tertiary hospital of southern Brazil," Journal of Infection and Chemotherapy, vol. 25, no. 4, pp. 293-297, 2019.

[163] E. D. d. A. Cruz, F. C. Pimenta, M. Hayashida, M. Eidt, and E. Gir, "Staphylococcus aureus detection in the mouth of housekeepers," Revista Latino-Americana de Enfermagem, vol. 19, no. 1, pp. 90-96, 2011.

[164] F. S. Cavalcante, R. P. Schuenck, D. C. Ferreira, C. R. da Costa, S. A. Nouér, and K. R. N. dos Santos, "Meticillinresistant Staphylococcus aureus: spread of specific lineages among patients in different wards at a Brazilian teaching hospital," Journal of Hospital Infection, vol. 86, no. 2, pp. 151-154, 2014.

[165] G. Santoro-Lopes, É. F. de Gouvêa, R. C. M. Monteiro et al., "Colonization with methicillin-resistant Staphylococcus aureus after liver transplantation," Liver Transplantation, vol. 11, no. 2, pp. 203-209, 2005.

[166] R. P. Schuenck, F. S. Cavalcante, E. Emery, M. Giambiagi-de Marval, and K. R. Netto dos Santos, "Staphylococcus aureus isolates belonging to different multilocus sequence types present specific virulence gene profiles," FEMS Immunology \& Medical Microbiology, vol. 65, no. 3, pp. 501-504, 2012.

[167] R. W. F. Cohen, T. W. Folescu, P. Daltro et al., "Methicillinresistant Staphylococcus aureus in cystic fibrosis patients: do we need to care? A cohort study," Sao Paulo Medical Journal, vol. 135, no. 5, pp. 420-427, 2017.

[168] C. R. S. Teodoro, C. S. Mattos, F. S. Cavalcante, E. M. Pereira, and K. R. N. d. Santos, "Characterization of MLSb resistance among Staphylococcus aureus and Staphylococcus epidermidis isolates carrying different SCCmec types," Microbiology and Immunology, vol. 56, no. 9, pp. 647-650, 2012.

[169] P. D. d. Matos, R. P. Schuenck, F. S. Cavalcante, R. M. Caboclo, and K. R. N. d. Santos, "Accuracy of phenotypic methicillin susceptibility methods in the detection of Staphylococcus aureus isolates carrying different SCCmec types," Memórias Do Instituto Oswaldo Cruz, vol. 105, no. 7, pp. 931-934, 2010.

[170] V. C. Salgueiro, M. D. A. L. Seixas, L. C. Guimarães et al., "High rate of neonates colonized by methicillin-resistant Staphylococcus species in an Intensive Care Unit," The Journal of Infection in Developing Countries, vol. 13, no. 9, pp. 810-816, 2019.

[171] P. V. Damasco, F. S. Cavalcante, R. C. Chamon et al., "The first case report of non-nosocomial healthcare-associated infective endocarditis due to methicillin-resistant Staphylococcus aureus USA400 in Rio de Janeiro, Brazil," Infection, vol. 41, no. 4, pp. 851-854, 2013.

[172] T. M. da Costa, P. G. M. Morgado, F. S. Cavalcante, A. P. Damasco, S. A. Nouér, and K. R. N. Dos Santos, "Clinical and microbiological characteristics of heteroresistant and vancomycin-intermediate Staphylococcus aureus from bloodstream infections in a Brazilian teaching hospital," PLoS One, vol. 11, no. 8, Article ID e0160506, 2016.

[173] A. P. Damasco, T. M. d. Costa, P. G. M. Morgado et al., "Daptomycin and vancomycin non-susceptible methicillinresistant Staphylococcus aureus clonal lineages from bloodstream infection in a Brazilian teaching hospital," The Brazilian Journal of Infectious Diseases, vol. 23, no. 2, pp. 139-142, 2019.

[174] F. S. Cavalcante, D. d. C. Ferreira, R. C. Chamon et al., "Daptomycin and methicillin-resistant Staphylococcus aureus isolated from a catheter-related bloodstream infection: a case report," BMC Research Notes, vol. 7, no. 1, pp. 759-9, 2014. 
[175] F. S. Cavalcante, E. D. Abad, Y. C. Lyra et al., "High prevalence of methicillin resistance and PVL genes among Staphylococcus aureus isolates from the nares and skin lesions of pediatric patients with atopic dermatitis," Brazilian Journal of Medical and Biological Research, vol. 48, no. 7, pp. 588-594, 2015.

[176] M. T. C. Vieira, M. A. Marlow, F. Aguiar-Alves et al., "Living conditions as a driving factor in persistent methicillin-resistant staphylococcus aureus colonization among HIV-infected youth," The Pediatric Infectious Disease Journal, vol. 35, no. 10, pp. 1126-1131, 2016.

[177] P. D. M. De Matos, T. L. R. De Oliveira, F. S. Cavalcante et al., "Molecular markers of antimicrobial resistance in methicillin-ResistantStaphylococcus aureusSCCmecIV presenting different genetic backgrounds," Microbial Drug Resistance, vol. 22, no. 8, pp. 700-706, 2016.

[178] L. R. Bastos, M. C. F. Martins, R. M. Albano, E. A. Marques, and R. S. Leão, "Whole genome sequencing of a ST2594 MRSA strain causing non-mucosal preoperative colonization and low-grade postoperative infection," Antonie Van Leeuwenhoek, vol. 112, no. 6, pp. 961-964, 2019.

[179] F. S. Cavalcante, E. d. D. Abad, A. C. F. Guimarães et al., "Rapid detection of methicillin-resistant staphylococcus aureus and SCCmec types from nasal swabs by multiplex PCR," The Journal of Infection in Developing Countries, vol. 10, no. 2, pp. 195-198, 2016.

[180] E. D. Abad, D. d. C. Ferreira, F. S. Cavalcante et al., "High incidence of acquiring methicillin-resistant Staphylococcus aureus in Brazilian children with Atopic Dermatitis and associated risk factors," Journal of Microbiology, Immunology and Infection, vol. 53, no. 5, pp. 724-730, 2020.

[181] C. Stephens, P. J.-Y. Cho, V. Afonso de Araujo et al., "Draft genome sequence of a community-associated methicillinresistant Panton-Valentine leukocidin-positive Staphylococcus aureus sequence type 30 isolate from a pediatric patient with a lung infection in Brazil," Genome Announcements, vol. 3, no. 4, pp. 3-4, 2015.

[182] D. C. M. d. Santos, T. M. d. Costa, R. F. Rabello, F. A. Alves, and S. S. B. d. Mondino, "Mannitol-negative methicillinresistant Staphylococcus aureus from nasal swab specimens in Brazil," Brazilian Journal of Microbiology, vol. 46, no. 2, pp. 531-533, 2015.

[183] I. M. Gomes, M. A. Marlow, M. G. Pinheiro et al., "Risk factors for Staphylococcus aureus and methicillin-resistant S aureus colonization among health care workers in pediatrics departments," American Journal of Infection Control, vol. 42, no. 8, pp. 918-920, 2014.

[184] B. M. F. B. Pires, F. P. De Oliveira, B. G. R. B. De Oliveira et al., "Monitoring and molecular characterization of Staphylococcus aureus isolated from chronic wounds," Advances in Skin \& Wound Care, vol. 31, no. 9, pp. 399-405, 2018.

[185] E. D. V. Braga, F. Aguiar-Alves, M. d. F. N. de Freitas et al., "High prevalence of Staphylococcus aureus and methicillinresistant $S$. aureuscolonization among healthy children attending public daycare centers in informal settlements in a large urban center in Brazil," BMC Infectious Diseases, vol. 14, no. 1, p. 538, 2014.

[186] F. P. G. Neves, M. A. Marlow, G. Rezende-Pereira et al., "Differences in gram-positive bacterial colonization and antimicrobial resistance among children in a high income inequality setting," BMC Infectious Diseases, vol. 19, no. 1, pp. 1-9, 2019.
[187] B. G. R. B. Oliveira, F. P. Oliveira, L. A. Teixeira, G. R. Paula, B. C. Oliveira, and B. M. F. B. Pires, "Epidermal growth factor vs platelet-rich plasma: activity against chronic wound microbiota," International Wound Journal, vol. 16, no. 6, pp. 1408-1415, 2019.

[188] M. Moreira, E. A. S. Medeiros, A. C. C. Pignatari, S. B. Wey, and D. M. Cardo, "Efeito da infecção hospitalar da corrente sanguínea por Staphylococcus aureus resistente à oxacilina sobre a letalidade e o tempo de hospitalização," Revista da Associação Médica Brasileira, vol. 44, no. 4, pp. 263-268, 1998.

[189] C. Helito, B. Zanon, H. Miyahara et al., "Clinical and epidemiological differences between septic arthritis of the knee and hip caused by oxacillin-sensitive and -resistant s. aureus," Clinics, vol. 70, no. 1, pp. 30-33, 2015.

[190] P. M. Vidal, P. A. Trindade, T. O. Garcia et al., "Differences between "classical" risk factors for infections caused by methicillin-resistant Staphylococcus aureus (MRSA) and risk factors for nosocomial bloodstream infections caused by multiple clones of the staphylococcal cassette ChromosomemecType IV MRSA strain," Infection Control \& Hospital Epidemiology, vol. 30, no. 2, pp. 139-145, 2009.

[191] C. Grothe, A. Belasco, A. Bettencourt et al., "Lethality of endocarditis due to $S$. aureus among patients on hemodialysis," Nephrology Nursing Journal, vol. 36, no. 6, pp. 613619, 2009.

[192] M. J. Mimica, E. N. Berezin, N. Damaceno, and R. B. Carvalho, "SCCmec type IV, PVL-negative, methicillinresistant Staphylococcus aureus in cystic fibrosis patients from Brazil," Current Microbiology, vol. 62, no. 2, pp. 388-390, 2011.

[193] A. Gales, H. Sader, S. Andrade, L. Lutz, A. Machado, and A. Barth, "Emergence of linezolid-resistant Staphylococcus aureus during treatment of pulmonary infection in a patient with cystic fibrosis," International Journal of Antimicrobial Agents, vol. 27, no. 4, pp. 300-302, 2006.

[194] R. L. Pacheco, R. D. Lobo, M. S. Oliveira et al., "Methicillinresistant Staphylococcus aureus (MRSA) carriage in a dermatology unit," Clinics, vol. 66, no. 12, pp. 2071-2077, 2011.

[195] M. J. Mimica, R. L. Carvalho, E. N. Berezin, N. Damaceno, and H. H. Caiaffa-Filho, "Comparison of five methods for oxacillin susceptibility testing of Staphylococcus aureus isolates from cystic fibrosis patients," Revista do Instituto de Medicina Tropical de São Paulo, vol. 54, no. 6, pp. 305-306, 2012.

[196] M. A. Cursino, C. P. Garcia, R. D. Lobo et al., "Performance of surveillance cultures at different body sites to identify asymptomatic Staphylococcus aureus carriers," Diagnostic Microbiology and Infectious Disease, vol. 74, no. 4, pp. 343-348, 2012.

[197] C. Grothe, A. G. d. S. Belasco, A. R. d. C. Bittencourt, L. A. C. Vianna, R. d. C. C. Sesso, and D. A. Barbosa, "Incidence of bloodstream infection among patients on hemodialysis by central venous catheter," Revista LatinoAmericana de Enfermagem, vol. 18, no. 1, pp. 73-80, 2010.

[198] P. R. Oliveira, V. C. Carvalho, C. da Silva Felix, A. P. de Paula, J. Santos-Silva, and A. L. L. M. Lima, "The incidence and microbiological profile of surgical site infections following internal fixation of closed and open fractures," Revista Brasileira de Ortopedia, vol. 51, no. 4, pp. 396-399, 2016.

[199] T. M. Bes, R. R. Martins, L. Perdigão et al., "Prevalence of methicillin-resistant Staphylococcus aureus colonization in individuals from the community in the city of Sao Paulo, 
Brazil," Revista do Instituto de Medicina Tropical de São Paulo, vol. 60, pp. 1-5, 2018.

[200] J. R. Spinardi, R. Berea, P. A. Orioli et al., "Enterococcus spp. and $S$. aureus colonization in neutropenic febrile children with cancer," GERMS, vol. 7, no. 2, pp. 61-72, 2017.

[201] F. S. Lupinacci, D. Bussius, F. Acquesta et al., "High prevalence of clindamycin resistance in Staphylococcus aureus blood culture isolates in São Paulo, Brazil," Journal of Laboratory Physicians, vol. 9, no. 4, pp. 314-316, 2017.

[202] L. Del'Alamo, P. A. D'Azevedo, A. J. Strob et al., “An outbreak of catalase-negative meticillin- resistant Staphylococcus aureus," Journal of Hospital Infection, vol. 65, no. 3, pp. 226-230, 2007.

[203] C. Cataneo, S. R. M. d. S. Canini, P. d. T. O. e. Castro, M. Hayashida, and E. Gir, "Evaluation of the sensitivity and specificity of criteria for isolation of patients admitted to a specialized cancer hospital," Revista Latino-Americana de Enfermagem, vol. 19, no. 5, pp. 1072-1079, 2011.

[204] T. E. Toscano Olivo, E. C. de Melo, C. Rocha, and C. M. C. B. Fortaleza, "Risk factors for acquisition of Methicillin-resistant Staphylococcus aureus among patients from a burn unit in Brazil," Burns, vol. 35, no. 8, pp. 1104-1111, 2009.

[205] C. R. Fortaleza, E. C. d. Melo, and C. M. C. B. Fortaleza, "Nasopharyngeal colonization with methicillin-resistant Staphylococcus aureus and mortality among patients in an intensive care unit," Revista Latino-Americana de Enfermagem, vol. 17, no. 5, pp. 677-682, 2009.

[206] E. C. d. Melo and C. M. C. B. Fortaleza, "Case-case-control study of risk factors for nasopharyngeal colonization with methicillin-resistant Staphylococcus aureus in a medicalsurgical intensive care unit," Brazilian Journal of Infectious Diseases, vol. 13, no. 6, pp. 398-402, 2009.

[207] J. P. d. Moura, F. C. Pimenta, M. Hayashida, E. D. d. A. Cruz, S. R. M. d. S. Canini, and E. Gir, "Colonization of nursing professionals by Staphylococcus aureus," Revista LatinoAmericana de Enfermagem, vol. 19, no. 2, pp. 325-331, 2011.

[208] L. A. F. Reinato, F. M. V. Pereira, L. P. Lopes, D. P. M. Pio, and E. Gir, "Colonização nasal em profissionais de enfermagem de unidades especializadas em HIV/aids," Revista Brasileira de Enfermagem, vol. 68, no. 2, pp. 320-324, 2015.

[209] J. B. Okado, S. C. Bogni, L. A. F. Reinato, R. Martinez, E. Gir, and I. L. B. d. C. Camargo, "Molecular analysis of methicillin-resistant Staphylococcus aureus dissemination among healthcare professionals and/or HIV patients from a tertiary hospital," Revista da Sociedade Brasileira de Medicina Tropical, vol. 49, no. 1, pp. 51-56, 2016.

[210] V. C. Pereira, A. Martins, L. M. Suppo de Souza Rugolo, and M. de Lourdes Ribeiro de Souza da Cunh, "Detection of oxacillin resistance in Staphylococcus aureus isolated from the neonatal and pediatric units of a Brazilian teaching hospital," Clinical Medicine Pediatrics, vol. 3, pp. 23-31, 2009.

[211] C. H. Camargo, M. d. L. R. d. S. Da Cunha, F. P. Bonesso, A. N. Da Cunha, C. M. C. B. Barbosa, and C. M. C. B. Fortaleza, "Systemic CA-MRSA infection following trauma during soccer match in inner Brazil: clinical and molecular characterization," Diagnostic Microbiology and Infectious Disease, vol. 76, no. 3, pp. 372-374, 2013.

[212] F. V. Pires, M. d. L. R. d. S. Da Cunha, L. M. Abraão, P. Y. F. Martins, C. H. Camargo, and C. M. C. B. Fortaleza, "Nasal carriage of Staphylococcus aureus in Botucatu, Brazil: a population-based survey," PLoS One, vol. 9, no. 3, Article ID e92537, 2014.
[213] E. P. L. Pereira-Franchi, M. R. N. Barreira, N. d. S. L. M. d. Costa, C. M. C. B. Fortaleza, and M. d. L. R. d. S. d. Cunha, "Prevalence of and risk factors associated with the presence of Staphylococcus aureus in the chronic wounds of patients treated in primary health care settings in Brazil," Revista da Sociedade Brasileira de Medicina Tropical, vol. 50, no. 6, pp. 833-838, 2017.

[214] C. Witzel, C. M. Castelo Branco Fortaleza, C. Sena Martins de Souza, D. Moraes Riboli, and M. d. L. Ribeiro de Souza da Cunha, "Nasopharyngeal carriage of Staphylococcus aureus among imprisoned males from Brazil without exposure to healthcare: risk factors and molecular characterization," Annals of Clinical Microbiology and Antimicrobials, vol. 13, no. 1, pp. 25-26, 2014.

[215] M. J. d. Carvalho, F. C. Pimenta, M. Hayashida et al., "Prevalence of methicillin-resistant and methicillin-susceptible s. aureus in the saliva of health professionals," Clinics, vol. 64, no. 4, pp. 295-302, 2009.

[216] M. C. Padoveze, A. T. Tresoldi, A. VonNowakonski, F. H. Aoki, and M. L. M. Branchini, "Nasal MRSA colonization of AIDS patients cared for in a Brazilian university hospital," Infection Control \& Hospital Epidemiology, vol. 22, no. 12 , pp. 783-785, 2001.

[217] G. C. Leite, M. C. Padoveze, and M. L. Moretti, "Methicillinresistance Staphylococcus aureus DNA electrophoretic pattern: temporal changes in an endemic hospital environment," Revista Panamericana de Salud Pública, vol. 30, no. 6, pp. 535-539, 2011.

[218] A. V. R. Vendemiato, A. Von Nowakonski, F. A. d. L. Marson, and C. E. Levy, "Microbiological characteristics of sepsis in a University hospital," BMC Infectious Diseases, vol. 15, no. 1, pp. 1-7, 2015.

[219] S. P. P. Falci, M. A. Teixeira, P. F. d. Chagas et al., "Antimicrobial activity of Melaleuca sp. Oil against clinical isolates of antibiotics resistant Staphylococcus aureus," Acta Cirurgica Brasileira, vol. 30, no. 7, pp. 491-496, 2015.

[220] M. M. Teixeira, M. C. Araújo, M. C. Silva-Carvalho et al., "Emergence of clonal complex 5 (CC5) methicillin-resistant Staphylococcus aureus (MRSA) isolates susceptible to trimethoprim-sulfamethoxazole in a Brazilian hospital," Brazilian Journal of Medical and Biological Research, vol. 45, no. 7, pp. 637-643, 2012.

[221] G. Sadoyama, K. R. N. D. Santos, A. P. Brilhante, and P. P. G. Filho, "Staphylococcus aureus as source of catheterrelated bloodstream infection evaluated by PFGE and repPCR typing in a Brazilian hospital," APMIS, vol. 116, no. 11, pp. 953-960, 2008.

[222] L. A. Rocha, R. Marques Ribas, A. L. Da Costa Darini, and P. P. Gontijo Filho, "Relationship between nasal colonization and ventilator-associated pneumonia and the role of the environment in transmission of Staphylococcus aureus in intensive care units," American Journal of Infection Control, vol. 41, no. 12, pp. 1236-1240, 2013.

[223] R. M. Ribas, C. Freitas, and P. P. Gontijo Filho, "Nosocomial bloodstream infections: organisms, risk factors and resistant phenotypes in the Brazilian University Hospital," Brazilian Journal of Infectious Diseases, vol. 11, no. 3, pp. 351-354, 2007.

[224] H. d. A. Silva, V. O. S. Abdallah, C. L. Carneiro, and P. P. Gontijo Filho, "Infection and colonization by Staphylococcus aureus in a high risk nursery of a Brazilian teaching hospital," Brazilian Journal of Infectious Diseases, vol. 7, no. 6, pp. 381-386, 2003. 
[225] C. C. S. P. Nery, I. A. Braga, R. M. Ribas, P. p. Gontijo Filho, and A. D. Filho, "Pressure ulcers colonized by MRSA as a reservoir and risk for MRSA bacteremia in patients at a Brazilian university hospital," Wounds, vol. 24, no. 3, pp. $67-75,2012$.

[226] C. S. d. Brito, L. L. Queiroz, P. A. d. Campos et al., "The nares as a CA-MRSA reservoir in the healthy elderly," Revista da Sociedade Brasileira de Medicina Tropical, vol. 48, no. 5, pp. 614-616, 2015.

[227] J. P. Porto, R. O. Santos, P. P. Gontijo Filho, R. M. Ribas, and R. M. Ribas, "Active surveillance to determine the impact of methicillin resistance on mortality in patients with bacteremia and influences of the use of antibiotics on the development of MRSA infection," Revista da Sociedade Brasileira de Medicina Tropical, vol. 46, no. 6, pp. 713-718, 2013.

[228] L. d. L. Bride, M. F. Pereira, M. C. Barbosa et al., "Differences in resistance profiles and virulence genes among methicillinresistant and methicillin-susceptible Staphylococcus aureus of different lineages at a public tertiary hospital," Revista da Sociedade Brasileira de Medicina Tropical, vol. 52, pp. 1-7, 2019.

[229] T. T. Gauna, E. Oshiro, Y. C. Luzio, A. M. M. Paniago, E. R. J. C. Pontes, and M. R. Chang, "Bloodstream infection in patients with end-stage renal disease in a teaching hospital in central-western Brazil," Revista da Sociedade Brasileira de Medicina Tropical, vol. 46, no. 4, pp. 426-432, 2013.

[230] A. O. Guilarde, M. D. Turchi, C. M. T. Martelli, and M. G. B. Primo, "Staphylococcus aureus bacteraemia: incidence, risk factors and predictors for death in a Brazilian teaching hospital," Journal of Hospital Infection, vol. 63, no. 3, pp. 330-336, 2006.

[231] A. O. Guilarde, M. D. Turchi, C. M. T. Martelli, M. G. B. Primo, and L. J. d. A. Batista, "Bacteremias em pacientes internados em hospital universitário," Revista da Associação Médica Brasileira, vol. 53, no. 1, pp. 34-38, 2007.

[232] J. O. Veloso, J. Lamaro-Cardoso, L. S. Neves et al., "Methicillin-resistant and vancomycin-intermediate Staphylococcus aureus colonizing patients and intensive care unit environment: virulence profile and genetic variability," Apmis, vol. 127, no. 11, pp. 717-726, 2019.

[233] J. Ribeiro, J. M. Boyce, and P. Q. Zancanaro, "Prevalence of methicillin-resistant Staphylococcus aureus (MRSA) among patients visiting the emergency room at a tertiary hospital in Brazil," Brazilian Journal of Infectious Diseases, vol. 9, no. 1, pp. 52-55, 2005.

[234] G. A. Oliveira, J. B. Faria, C. E. Levyand, and E. M. Mamizuka, "Characterization of the Brazilian endemic clone of methicillin-resistant Staphylococcus aureus (MRSA) from hospitals throughout Brazil," Brazilian Journal of Infectious Diseases, vol. 5, no. 4, pp. 163-170, 2001.

[235] A. Timerman, C. Brites, E. Bicudo et al., "Brazilian experience in EU-CORE: daptomycin registry and treatment of serious Gram-positive infections," The Brazilian Journal of Infectious Diseases, vol. 17, no. 6, pp. 647-653, 2013.

[236] IBGE, Instituto Brasileiro de Geografia e Estatística. Estatísticas Sociais, IBGE, Rio de Janeiro, Brazil, 2019, https://www.ibge.gov.br/. 